\title{
Human $\beta$-Defensin 2 Mediated Immune Modulation as Treatment for Experimental Colitis
}

\section{OPEN ACCESS}

Edited by:

Charles Lee Bevins,

University of California, Davis,

United States

Reviewed by:

Eduardo Ruben Cobo,

University of Calgary, Canada

Neeloffer Mookherjee,

University of Manitoba, Canada

*Correspondence:

Benjamin A. H. Jensen

benjamin.jensen@sund.ku.dk

tThese authors have contributed equally to this work

¥These authors share senior authorship

Specialty section: This article was submitted to

Microbial Immunology,

a section of the journal

Frontiers in Immunology

Received: 25 October 2019

Accepted: 14 January 2020

Published: 31 January 2020

Citation:

Koeninger L, Armbruster NS, Brinch KS, Kjaerulf S, Andersen B,

Langnau $C$, Autenrieth SE,

Schneidawind D, Stange EF, Malek NP, Nordkild P. Jensen BAH and Wehkamp J (2020) Human $\beta$-Defensin

2 Mediated Immune Modulation as Treatment for Experimental Colitis.

Front. Immunol. 11:93. doi: 10.3389/fimmu.2020.00093
Louis Koeninger ${ }^{1 \dagger}$, Nicole S. Armbruster ${ }^{1 \dagger}$, Karoline Sidelmann Brinch ${ }^{2}$, Søren Kjaerulf ${ }^{2}$, Birgitte Andersen ${ }^{2}$, Carolin Langnau ${ }^{3}$, Stella E. Autenrieth ${ }^{3}$, Dominik Schneidawind ${ }^{3}$, Eduard F. Stange ${ }^{1}$, Nisar P. Malek ${ }^{1}$, Peter Nordkild ${ }^{4}$, Benjamin A. H. Jensen ${ }^{5,6 * \neq}$ and Jan Wehkamp ${ }^{1 \neq}$

${ }^{1}$ Department of Internal Medicine I, University Hospital Tübingen, Tübingen, Germany, ${ }^{2}$ Novozymes, Bagsvaerd, Denmark, ${ }^{3}$ Department of Internal Medicine II, University Hospital Tübingen, Tübingen, Germany, ${ }^{4}$ Defensin Therapeutics, Copenhagen, Denmark, ${ }^{5}$ Department of Medicine, Faculty of Medicine, Cardiology Axis, Quebec Heart and Lung Institute, Laval University, Quebec, QC, Canada, ${ }^{6}$ Section for Human Genomics and Metagenomics in Metabolism, Faculty of Health and Medical Sciences, Novo Nordisk Foundation Center for Basic Metabolic Research, University of Copenhagen, Copenhagen, Denmark

Defensins represents an integral part of the innate immune system serving to ward off potential pathogens and to protect the intestinal barrier from microbial encroachment. In addition to their antimicrobial activities, defensins in general, and human $\beta$-defensin 2 (hBD2) in particular, also exhibit immunomodulatory capabilities. In this report, we assessed the therapeutic efficacy of systemically administered recombinant hBD2 to ameliorate intestinal inflammation in three distinct animal models of inflammatory bowel disease; i.e., chemically induced mucosal injury (DSS), loss of mucosal tolerance (TNBS), and T-cell transfer into immunodeficient recipient mice. Treatment efficacy was confirmed in all tested models, where systemically administered hBD2 mitigated inflammation, improved disease activity index, and hindered colitis-induced body weight loss on par with anti-TNF- $\alpha$ and steroids. Treatment of lipopolysaccharide (LPS)-activated human peripheral blood mononuclear cells with rhBD2 confirmed the immunomodulatory capacity in the circulatory compartment. Subsequent analyzes revealed dendritic cells (DCs) as the main target population. Suppression of LPS-induced inflammation was dependent on chemokine receptor 2 (CCR2) expression. Mechanistically, hBD2 engaged with CCR2 on its DC target cell to decrease NF-кB, and increase CREB phosphorylation, hence curbing inflammation. To our knowledge, this is the first study showing in vivo efficacy of a systemically administered defensin in experimental disease.

Keywords: host defense peptides, antimicrobial peptides, $\beta$-defensins, IBD, innate immunity

\section{INTRODUCTION}

Inflammatory bowel diseases (IBD) are multifactorial disorders characterized by chronic relapsing inflammation of the intestine (1). They currently affect more than 4 million patients worldwide (2) and are classified in two major entities, Crohn's disease (CD) and ulcerative colitis (UC). While UC is mainly restricted to the colonic mucosa, $\mathrm{CD}$ can occur at any site of the gastrointestinal tract but predominantly in the terminal ileum and colon, and inflammation is typically transmural (3). 
The etiology of the different forms of IBD is not fully understood. It has, however, been demonstrated that differential defects of the intestinal antimicrobial barrier play an important role in the pathogenesis of both $\mathrm{CD}$ and UC (4). Genetic analysis revealed that small intestinal vs. colonic $\mathrm{CD}$ are different disease entities and are characterized by distinct but overlapping genetic signatures (5). Moreover, in UC compromised mucus production, due to depletion of goblet cells, is a key triggering event in disease pathology, whereas $\mathrm{CD}$ is characterized by a defective intestinal barrier, which associates with complex defensin deficiencies based on a variety of mechanisms (6-10). The best described genetic links to small intestinal CD (11), i.e., NOD2, ATG16L1, XBPD1, are functionally involved in Paneth cell function (12-15). Paneth cells of the small intestine secrete different antimicrobial peptides into the intestinal lumen. Other mechanisms involving compromised $\alpha$-defensin regulation of Paneth cells include the Wnt signaling pathway (16). A reduced monocyte derived Wnt ligand secretion in $\mathrm{CD}$ may further diminish Paneth cells and defensin expression (10). In the colon, we and others have shown an attenuated induction of the inducible human $\beta$-defensin 2 (hBD2) in CD patients, although the mechanisms remains elusive (7).

Defensins represent an ancient highly conserved part of the innate immune system. Most of these small endogenous peptides possess broad-spectrum antimicrobial activity as well as immunomodulatory functions. In humans, granulocytes as well as Paneth cells secrete different $\alpha$-defensins whereas $\beta$-defensins are expressed by epithelial surfaces throughout the body (17). hBD2 was discovered using a functional antimicrobial readout by Harder and Schröder in the skin (18). As shown in vitro hBD2 has strong antimicrobial and immunomodulatory functions and is induced by inflammatory stimuli or exogenous microbial substances (19). hBD2 promotes intestinal wound healing (19) and angiogenesis (20) in vitro and can act as a chemoattractant for dendritic cells (DCs), monocytes and T-cells through interaction with the chemokine receptor 2 (CCR2) and 6 (CCR6) (21, 22). Thus, in addition to a lack of mucosal antibacterial activity (23) low defensin expression may also translate into a repressed antiinflammatory activity. Together, these data provide evidence for an important role of defensins, including $\mathrm{hBD} 2$, in IBD disease pathogenesis and potential therapy, but its mode of action in vivo and their potential role as therapeutics remains to be described.

Standard therapy in IBD is based on immunosuppression with glucocorticosteroids and azathioprine as short and long term therapy, respectively. Antibodies that target tumor necrosis factor alpha $(\mathrm{TNF} \alpha)$ attenuate disease-related inflammatory pathways rather than act as a general immunosuppressants, but $20-40 \%$ of patients are primary TNF $\alpha$ non-responders and up to $50 \%$ lose their effective response over time, termed secondary non-responders $(24,25)$. Despite successful development of other biologicals against specific targets like integrins or IL-12/23, the medical need for alternative therapeutic strategies targeting the molecular mechanisms underlying IBD is still high, providing a sound rationale for examining $\mathrm{hBD} 2$ as a potential biological therapy for the treatment of IBD and potentially other barrier function related inflammatory disorders. However, a major limitation for considering development of hBD2 was the difficulty to produce sufficient quantities of defensin peptides at industrial scale. We have therefore developed a cost efficient large-scale production method of recombinant hBD2 (26). In this study, we hypothesized that hBD2 could act as an anti-inflammatory peptide independently of its classical antimicrobial function. We found that recombinant hBD2 suppressed DC-mediated secretion of proinflammatory cytokines such as TNF- $\alpha$, IL12 and IL-1 $\beta$. The mechanism was dependent on CCR2 signaling leading to a reduced NF- $\kappa \mathrm{B}$ but increased CREB phosphorylation. Extending the in vitro findings, we next assessed the capability of hBD2 to suppress IBD in three different animal models of experimental colitis. We administered the therapeutic agent by subcutaneous injections to uncouple its classical antimicrobial actions from its immunomodulatory capabilities. hBD2 administration significantly improved the responding phenotype in both DSS-, TNBS-, and T-cell induced colitis, hence corroborating broad treatment efficacy in discrepant gastrointestinal disease pathologies. These data represent the first in vivo evidence that a human defensin, such as hBD2, offers a systemic, anti-inflammatory biologic agent, which could be used as a promising future therapeutic against human IBD.

\section{MATERIALS AND METHODS}

\section{Human Blood Samples}

In this study blood was obtained from healthy individuals (males and females in 1:1 ratio) that gave their written and informed consent after they were informed about the study purpose, sample procedure, and potential adjunctive risks. The study protocol was previously approved by the Ethical Committee of the University Hospital, Tübingen, Germany and the Ethical Committee of Region Capital, Denmark (Den Videnskabsetiske komite Region Hovedstaden).

\section{Production and Purification of Recombinant hBD2}

Recombinant hBD2 was expressed in E. coli as a his-tagged thioredoxin fusion protein with an enterokinase cleavage site and purified essentially as described in the patent (WO2010/007166 Treatment of inflammatory bowel diseases with human $\beta$ defensin 2). An additional reversed phase purification step was included to ensure removal of endotoxins. The processed and purified hBD2 was diluted in water for injection supplemented with $1 \% \mathrm{v} / \mathrm{v}$ formic acid and bound to a Daisogel SP-120C18 column and eluted with $1 \% \mathrm{v} / \mathrm{v}$ formic acid in $30 \%$ $\mathrm{v} / \mathrm{v}$ ethanol. The solvents were removed by evaporation in a speed-vac and the final product formulated in PBS before use. The proper folding and disulphide-bridge topology was verified using tryptic digestion coupled with LC-MS/MS and NMR spectroscopy. The purified hBD2 (endotoxin levels < $0.05 \mathrm{EU} / \mathrm{ml}$ ) were kept in its natural tertiary structure with purity $\geq 96 \%$. 


\section{In vitro Toxicity Tests Red Blood Cell Assay}

Blood was collected using EDTA as anticoagulant and diluted in PBS to obtain an $8 \%$ red blood cell suspension. One part of the red blood cell suspension was added to three parts of test material (dissolved in PBS) in a poly propylene plate. One percent sodium dodecyl sulfate (SDS) was used as a positive control. Assay mixtures were incubated for $60 \mathrm{~min}$ at $37^{\circ} \mathrm{C}$ under constant agitation of the plate. Incubation was terminated by centrifugation at 2,000 rpm for 2-3 min. $50 \mu \mathrm{l}$ of the supernatants were transferred to a microtiter plate and measured at $540 \mathrm{~nm}$.

\section{Murine Fibroblasts L929 Neutral Red Uptake}

Cytotoxicity was measured by the neutral red uptake procedure of Borenfreund and Puerner, using mouse L929 fibroblasts (ATCC ${ }^{\circledR}$ CCL-1 ${ }^{\mathrm{TM}}$ ) and a $24 \mathrm{~h}$ exposure to hBD2 (27). L929 fibroblasts were grown in EMEM supplemented with $10 \%$ fetal bovine serum (FBS). For testing $7.5 \times 10^{4}$ cells were seeded into 96 well plates and incubated for $24 \mathrm{~h}$ at $37^{\circ} \mathrm{C}$ to establish a near confluent monolayer. Cells were challenged with the indicated concentrations of hBD2, SDS was used as control.

\section{In vivo Toxicity Test}

In vivo toxicity of hBD2 was assessed in 6-8 weeks old female NMRI mice (Taconic Europe). All animal studies were performed according to Danish legislations for laboratory animals and approved by Novozymes science ethics committee. hBD2 was given subcutaneously (s.c.) in the intrascapular region using a $25 \mathrm{G}$ needle and a $1 \mathrm{ml}$ syringe. Animals were dosed on day 0 with the indicated amount of hBD2, applied as $10 \mathrm{mg} / \mathrm{kg}$ according to the individual body weight. Clinical signs were recorded on day 0 and monitored until experimental endpoints. Body weights were recorded as a minimum on day 0 , day 2 , and day 4 prior to euthanasia. Necropsy was performed after euthanasia and kidneys, spleens and livers were weighed.

\section{Pharmacokinetic Profile of hBD2}

Two groups of female NMRI mice were weighed and injected s.c. with either $1 \mathrm{mg} / \mathrm{kg}(n=4)$ or $10 \mathrm{mg} / \mathrm{kg}(n=3) \mathrm{hBD} 2$ in $300 \mu \mathrm{l}$. HBD2 was diluted in $10 \mathrm{mM}$ sodium acetate in $0.9 \% \mathrm{NaCl}$. Blood samples were collected at different time points and stored at room temperature for a minimum of $20 \mathrm{~min}$ before centrifugation at $2,000 \times \mathrm{g}$ for $10 \mathrm{~min}$. Serum was separated and stored at $-20^{\circ} \mathrm{C}$ until analysis. Serum from the group that received $10 \mathrm{mg} / \mathrm{kg}$ was analyzed by LC-MS/MS, the serum from the other group was analyzed by HPLC.

\section{Stimulation of Peripheral Blood Mononuclear Cells (PBMCs)}

Heparinized blood was diluted 1/1 v/v with RPMI (Gibco) and was subjected to Ficoll-Paque Plus (GE healthcare) density centrifugation within $2 \mathrm{~h}$ of drawing. Plasma was collected from the top from individual donors and was kept on ice until it was used at $2 \%$ in the culture medium (autologous culture medium). Isolated PBMC's were re-suspended in autologous culture medium and seeded in 96-well culture plates with 115.500 cells per well (Figure 1) or 200.000 cells per well (Figure 2) in a total of $200 \mu \mathrm{l}$. PBMC's from the same donor were stimulated with 100,10 or $1 \mu \mathrm{g} / \mathrm{ml}$ of $\mathrm{hBD} 2$ either alone or together with $20 \mathrm{pg} / \mathrm{ml}$ lipopolysaccharide (LPS) (E. coli, O111:B4, Sigma L4391) or with $0.3 \mu \mathrm{g} / \mathrm{ml}$ Pam3CSK4 (InvivoGen). The supernatants were collected after incubation at $37^{\circ} \mathrm{C}$ for $24 \mathrm{~h}$, and stored at $-80^{\circ} \mathrm{C}$ until cytokine measurement.

The experiment in Figure 1 was performed with healthy volunteers, which were recruited under an approval from the Ethical Committee for Region Capital, Denmark. Interleukin $1 \beta$ (IL-1 $\beta$ ) and tumor necrosis factor alpha (TNF- $\alpha$ ) (Figure 1) were quantified in supernatants by flow cytometry using a human inflammation cytometric bead array (CBA) according to manufacturer's instructions (BD) using a FACSarray flow

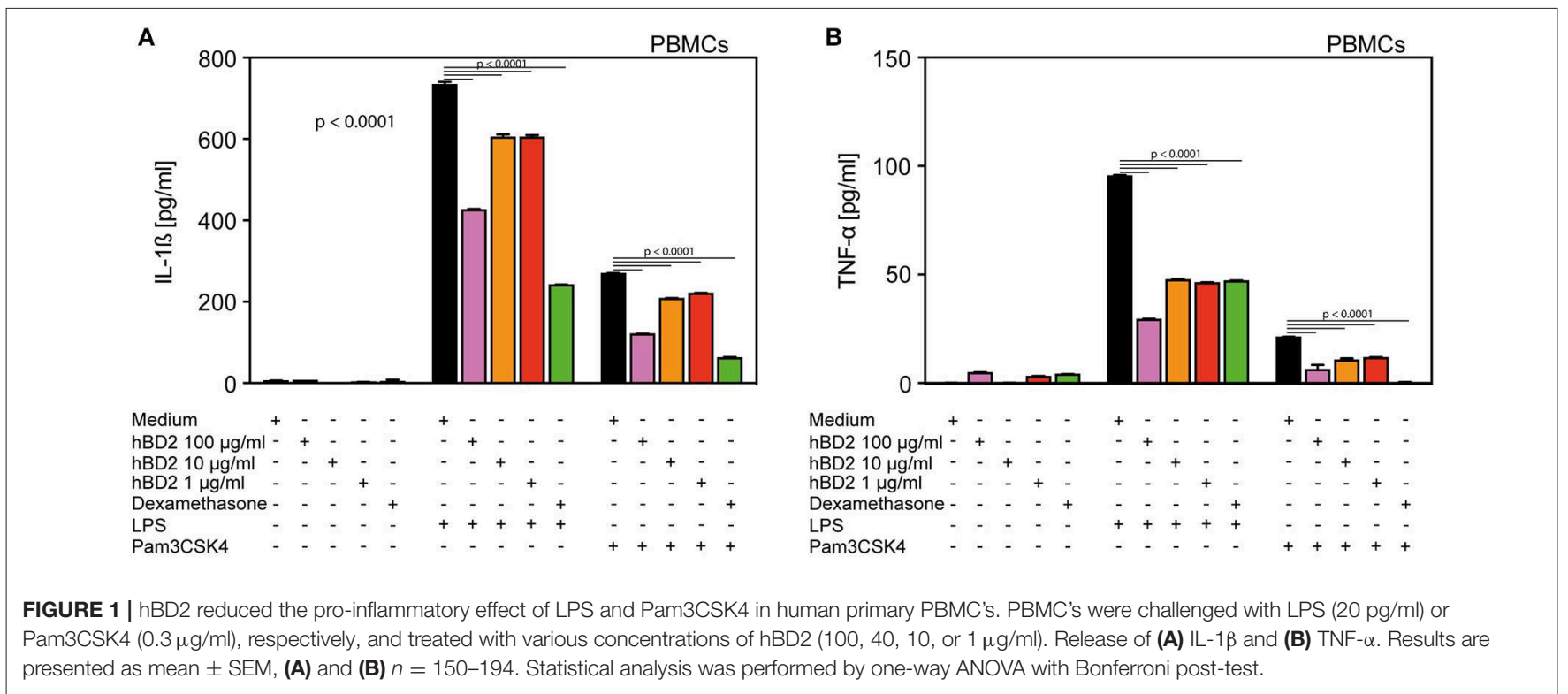


A

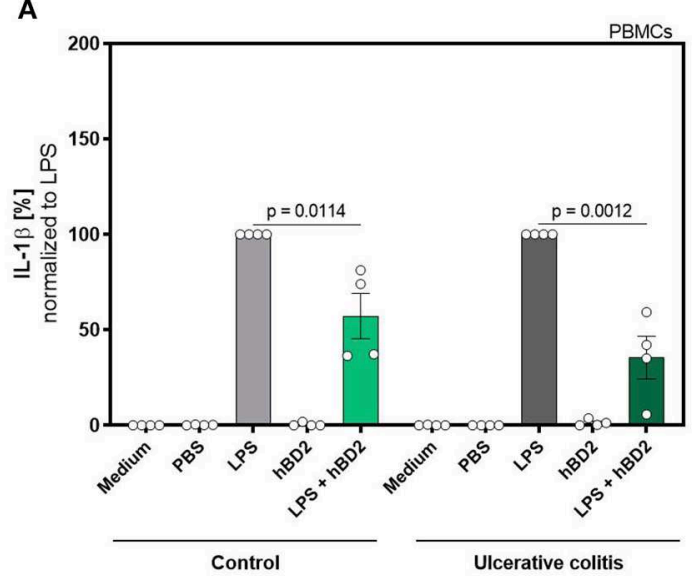

C

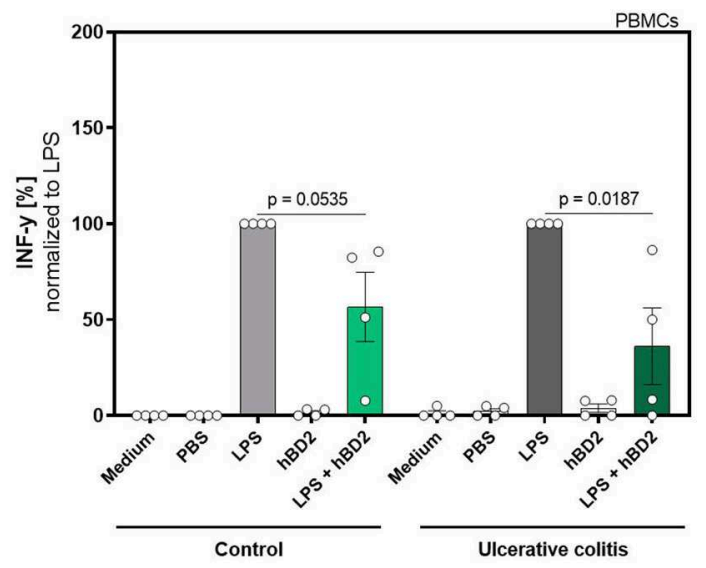

E

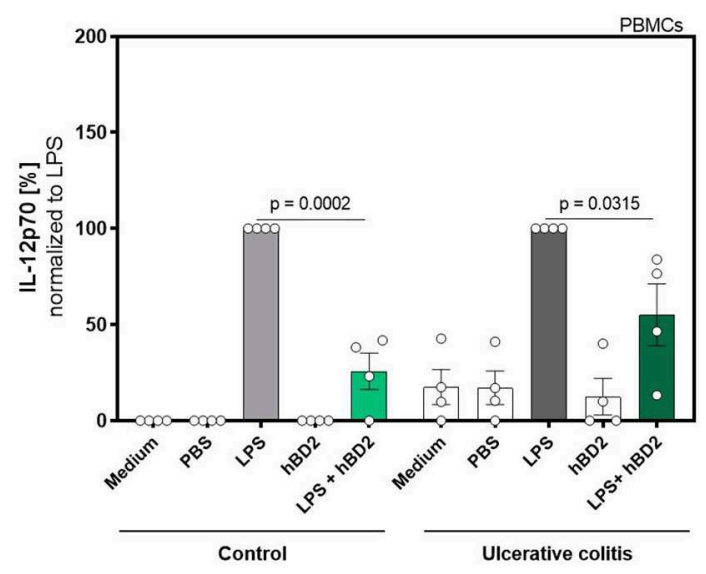

B

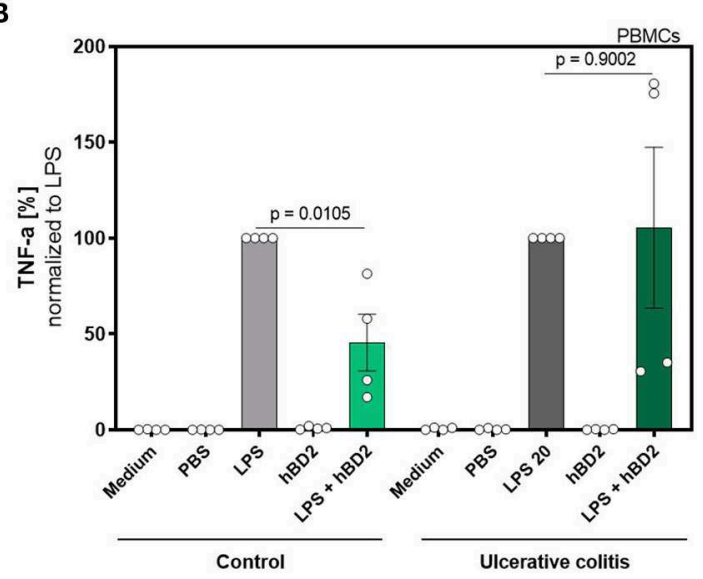

D

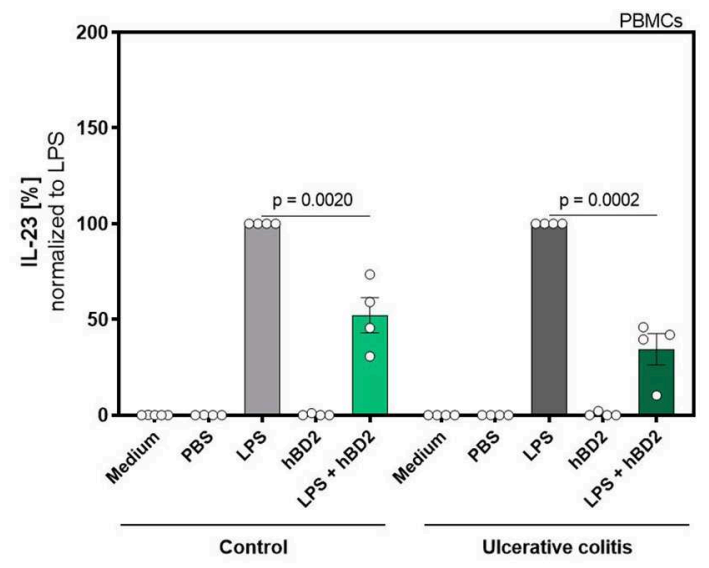

FIGURE 2 | hBD2 reduced the pro-inflammatory effect of LPS in human primary PBMC's of ulcerative colitis patients. PBMC's were challenged with LPS (20 pg/ml) and treated with $10 \mu \mathrm{g} / \mathrm{mL}$ hBD2. Release of of (A) IL-1 $\beta$, (B) TNF- $\alpha$, (C) INF-y, (D) IL-23, and (E) IL-12p70 is shown in \% normalized to LPS. Data are presented as mean $\pm \operatorname{SEM}(n=4)$ and analyzed by unpaired $t$-test.

cytometer. IL-1 $\beta$, TNF- $\alpha$, Interferon gamma (INF-y), Interleukin 12p70 (IL-12), and Interleukin 23 (IL-23) were analyzed using a human inflammation cytometric bead array (LegendPlex Biolegends) according to manufacturer's instructions.
The experiment in Figure 2 was performed with 8 subjects (4 controls and 4 colitis patients) to study the impact of disease status on treatment efficacy. Clinical status of these subjects were subtotal remission 
(Simponi and Salofalk), remission (Vedolizumab), mild disease (Infliximab, Salofalk, and Prednisolon), and moderate disease (Vedolizumab). PBMCs from these subjects were analyzed for IL-1b, TNF-a, IFN-g, IL12, and IL-23 expression using a human inflammation cytometric bead array (LegendPlex Biolegends) according to manufacturer's instructions.

\section{Generation of Human Monocyte-Derived Dendritic Cells (Mo-DCs)}

Peripheral blood was drawn from healthy donors and diluted one to one in PBS. The mixture was stacked in a falcon tube on Biocoll separation solution (Biochrome) with a ratio of three parts blood PBS mixture to two parts Biocoll. For a density gradient centrifugation the falcon tubes were centrifuged at 2,000 rpm for $30 \mathrm{~min}$ at RT. The PBMC's were removed and washed twice with PBS. $1.5 \times 10^{6}$ cells were seeded per well in a tissue culture-treated 6-well plate in RPMI-1640 medium (Merck) supplemented with $10 \%$ fetal calf serum (FCS; Sigma-Aldrich), $2 \mathrm{mM}$ L-glutamine (Biochrome), $100 \mathrm{U} / \mathrm{ml}$ penicillin/streptomycin (Gibco), $50 \mu \mathrm{M}$ 2-mercaptoethanol (Fluka), $1 \mathrm{mM}$ sodium pyruvate (Biochrome), and $1 \mathrm{x}$ non-essential amino acids (Biochrome) and incubated for $1 \mathrm{~h}$ at $37^{\circ} \mathrm{C}$ and $5 \% \mathrm{CO}_{2}$ for monocyte adherence. Then the cells were washed with media and PBS to remove the non-adherent cells and were cultivated for 6 days with media additional supplemented with $50 \mathrm{ng}$ IL-4 and 100 ng GM-CSF (Miltenyi). Cytokines were added a second and third time on day 2 and 4 whereas the cells were harvested at day 6.

\section{Generation of Bone Marrow-Derived Dendritic Cells (BM-DCs)}

BM-DC's were generated using granulocyte-macrophage colony-stimulating factor (GM-CSF) and RPMI-1640 medium (Merck) supplemented with $10 \%$ fetal calf serum (FBS; Life Technologies), $2 \mathrm{mM}$ glutamine (Thermo Fisher), $100 \mathrm{U} / \mathrm{ml}$ penicillin/streptomycin (Gibco), $50 \mu \mathrm{M}$ 2-mercaptoethanol (Roth), $1 \mathrm{mM}$ sodium pyruvate (Biochrome), and $1 \mathrm{x}$ non-essential amino acids (Biochrome) as previously described (28). Shortly, $2 \times 10^{6}$ bone marrow cells flushed from the tibias and femurs of $\mathrm{C} 57 \mathrm{BL} / 6$ mice were seeded in dishes containing $200 \mathrm{U} / \mathrm{ml}$ GM-CSF. After 3 days extra medium containing GM-CSF was added to the cells and on day 6 half of the medium was replaced by fresh serum containing GM-CSF. After 7 or 8 days slightly attached cells were harvested. Female C57BL/6JolaHsd mice were purchased from Janvier (St. Berthevin Cedex, France). Animal experiments were performed in strict accordance with the German regulations of the Society for Laboratory Animal Science (GVSOLAS) and the European Health Law of the Federation of Laboratory Animal Science Associations (FELASA). The protocol was approved by the Regierungspräsidium Tübingen (Anzeige 09.01.2014).

\section{Cytokine Production by Human Mo-DC's and Murine BM-DC's}

$2 \times 10^{5}$ murine BM-DC's or human Mo-DC's were seeded in 96-well round bottom plates. First they were pretreated with $100 \mathrm{ng} / \mathrm{ml}$ pertussis toxin (Sigma-Aldrich) or $5 \mu \mathrm{M}$ of the CCR2 inhibitor RS 504393 (Tocris) and subsequently stimulated with $100 \mathrm{ng} / \mathrm{ml}$ LPS or $0.2 \mathrm{mg} / \mathrm{ml}$ TNF- $\alpha, 0.2$ $\mathrm{mg} / \mathrm{ml} \mathrm{IL}-6$ and $0.2 \mathrm{mg} / \mathrm{ml} \mathrm{IL}-1 \beta$ and $10 \mu \mathrm{g} / \mathrm{ml}$ or $100 \mu \mathrm{g} / \mathrm{ml}$ $\mathrm{hBD} 2$. $24 \mathrm{~h}$ later supernatants were collected and TNF- $\alpha$ [Biolegend (BM-DC's); R\&D (Mo-DC's)] was analyzed according to the manufacturer's instructions. IL-10, IL-12, and IL-1 $\beta$ (LEGENDplex Biolegend) was as well-analyzed according to the manufacturer's instructions.

\section{Flow Cytometry}

$2 \times 10^{5}$ murine BM-DC's were seeded in 96-well round bottom plates and treated as described above. Cells were removed from the plate using Accutase (Sigma-Aldrich) and stained for $20 \mathrm{~min}$ at room temperature with Zombie Aqua (Biolegend) to exclude dead cells and extracellular antibodies against CD11cAPC (N418) (Miltenyi), MHCII-FITC (M5/114.15.2) (Miltenyi) and CD86-BV421 (GL-1) (Biolegend). For p-CREB staining cells were fixed and permeabilized with Foxp3 Staining Buffer Set (eBioscience) and stained with primary antibody phosphorCREB mAb (Ser133; clone 87G3) (Cell Signaling) for $30 \mathrm{~min}$ in the dark at room temperature followed by secondary goat antirabbit IgG-DyLight ${ }^{\mathrm{TM}} 649$ (Jackson ImmunoResearch) for $15 \mathrm{~min}$ at $4{ }^{\circ} \mathrm{C}$. To detect intracellular p-NF- $\kappa \mathrm{B}$ BM-DCs were fixed with $2 \%$ paraformaldehyde (VWR) in PBS, permeabilized with $90 \%$ freezing methanol (Applichem) and stained with the primary antibodies to phosphor-NF- $\kappa$ B p65 (93H1) (Cell Signaling) for $60 \mathrm{~min}$ in the dark at room temperature followed by goat antirabbit IgG-PE-Cy7 (Santa Cruz Biotechnology) for $15 \mathrm{~min}$ at $4^{\circ} \mathrm{C}$. PBS with $0,5 \%$ bovine serum albumin (Biomol) was used for all incubations and washing steps. At least 50,000 cells were acquired using a Canto-II flow cytometer (BD nces) with DIVA software (BD Biosciences) and were further analyzed using FlowJo 10.5 software (Tree Star).

\section{DSS Colitis Model}

The DSS colitis study was performed by Farma-Cros Ibérica according to directive 86/609 EEC and approved by Novozymes science ethics committee. $7-8$ weeks old male C57BL/6 mice were used (Charles River) and each group consisted of 10 animals. Animal allocation to all experimental groups was done in a randomized manner. Colitis was induced by supplementing the drinking water with $2 \%$ dextran sodium sulfate (DSS, 30-50 kDA, MP Biomedicals) for 7 days. On day 1 all mice were weighed and the drinking bottle was filled with the DSS solution, this solution was replaced on day 3 and 5. On day 8 the remaining solution was discarded and replaced with autoclaved water. Mice were divided into 3 groups. One group received PBS as sham treatment intravenously. One group received on day 1,4 , and 8 , $300 \mu \mathrm{g} /$ mouse of a mouse anti-TNF- $\alpha$ antibody ( $\alpha$ TNF, Ramcon) intraperitoneally. The animals in the other group were dosed s.c. with $0.1 \mathrm{mg} / \mathrm{kg} \mathrm{hBD} 2$ once a day, starting at day 1 until day 10 . Animals were euthenized on day 10. Daily clinical assessment was 
carried out to calculate a validated clinical disease activity index (DAI) ranging from 0 to 4 according to the following parameters: body weight loss, presence or absence of rectal bleeding, stool consistency. One mouse in the DSS control group had to be euthanized before the end of the study.

\section{TNBS Colitis Model}

The TNBS colitis study was performed by Farma-Cros Ibérica according to directive 86/609 EEC and approved by Novozymes science ethics committee. Male BALB/cByJ mice were used (Janvier) and each group consisted of 15 animals. Animal allocation to all experimental groups was done in a randomized manner. Colitis was induced on day 0 by intracolonic (distal) administration of trinitrobenzene sulfonic acid (TNBS), $1 \mathrm{mg} / \mathrm{mouse}$ in 50\% ethanol under mild anesthesia (ketamine/xylazine). Treatment of the animals started on day 0 after induction of colitis. All compounds were applied s.c. Mice received PBS (TNBS control), Prednisolone (10 mg/kg), or hBD2 $0.1 \mathrm{mg} / \mathrm{kg}$ ), respectively. In the TNBS control group as well as in the Prednisolone group, 2 animals had to be sacrificed before the end of the experiment. All other animals were sacrificed on day 10. Daily clinical assessment was carried out to calculate a validated clinical DAI ranging from 0 to 4 according to the following parameters: body weight loss, presence or absence of rectal bleeding, stool consistency.

\section{T Cell Colitis Model}

This study was performed by the Department of Biomedical Science at the University of Catania according to directive 86/609 EEC and approved by Novozymes science ethics committee. 8 weeks old female BALB/c and C.B-17 female SCID mice were purchased from Harlan (Italy). Colitis was induced in severe combined immunodeficiency (SCID) mice by transplantation of $\mathrm{CD}^{+} / \mathrm{CD} 25^{-} \mathrm{T}$ cells from the $\mathrm{BALB} / \mathrm{c}$ mice. Briefly, lymphomonocytes isolated from spleen or lymph nodes from $\mathrm{BALB} / \mathrm{c}$ mice were subjected to negative selection of $\mathrm{CD} 4^{+} \mathrm{T}$ cells. Afterwards, $\mathrm{CD} 4^{+} / \mathrm{CD} 25^{+}$cells were positively isolated by binding to the beads from the $\mathrm{CD} 4^{+} \mathrm{T}$ cell suspensions and the $\mathrm{CD} 4^{+} / \mathrm{CD} 25^{-}$were collected from supernatant. Cell preparation was considered successful if the analysis of purified cells by flow cytometry (FACSCalibur, BD Bioscience, Heidelberg, Germany) using CellQuest software showed that $>95 \%$ of the cells were viable (based on forward and side-scatter characteristics and/or 7- actynomycin-D staining) and CD4-positive (using a FITC-conjugated anti-mouse CD4-antibody, BD, Heidelberg, Germany), as well as more than 98\% depleted of CD25 (using a APC-conjugated anti-mouse CD25-antibody, BD, Heidelberg, Germany). $\mathrm{CD} 4{ }^{+} / \mathrm{CD} 25^{-}$cells were intraperitoneally injected to SCID mice at a concentration of 500,000 cells in a final volume of $0.2 \mathrm{ml}$ RPMI 1640. Sham treated animals $(n=6)$ received $0.2 \mathrm{ml}$ pure RPMI 1640. Diseased mice were randomized divided into 4 groups $(n=11)$ and treated once daily by s.c. application of PBS (vehicle), hBD2 (0.1 and $1 \mathrm{mg} / \mathrm{kg}$, respectively) or $0.3 \mathrm{mg} / \mathrm{kg}$ Dexamethasone (Dexa., applied intraperitoneally). Treatments started 7 days post $\mathrm{T}$ cell transfer and continued daily for 86 days. Animals were weighed three times a week and monitored twice a week starting from day 42 for the clinical status, summarized as
DAI. The DAI included body weight loss, stool consistency, and the presence of blood at the rectum. One animal in the vehicle and one in the Dexamethasone treated groups had to be sacrificed before the end of the study. At the end of the study, animals were sacrificed and the colon was removed and carefully cleaned for further analysis. First, the colon was weighed then a section from the middle was removed and fixed for pathologic survey. The rest of the colon $(5 \mathrm{~cm})$ was used to quantify the activity of myeloperoxidase in the tissue.

\section{Myeloperoxidase Activity Assay}

Myeloperoxidase activity was performed on $5 \mathrm{~cm}$ of colon previously frozen at $-80^{\circ} \mathrm{C}$. Colon was homogenized in $0.5 \%$ of HETAB dissolved in $10 \mathrm{mM}$ of Phosphate-Citrate Buffer ( $\mathrm{pH}$ 7.0) to enable the release of MPO enzyme from the neutrophil granules. Homogenated samples after three freezethaw cycles were spun at $3,000 \times \mathrm{g}$ at $4^{\circ} \mathrm{C}$ for $30 \mathrm{~min}$. Pellets were resuspended in $0.5 \%$ HETAB in $10 \mathrm{mM}$ Phosphate-Citrate Buffer and spun again at $3,000 \times \mathrm{g}$ at $4^{\circ} \mathrm{C}$ for $30 \mathrm{~min}$. 500 ul of supernatant were delivered into a vial along with 500 ul of TMB in Phosphate-Citrate Buffer containing Perborate Sodium. Changes in absorbance at 620 and $450 \mathrm{~nm}$ were read by a spectrophotometer (IRIS). Peroxidase enzyme diluted in $0.5 \%$ HETAB in $10 \mathrm{mM}$ Phosphate-Citrate Buffer and $\mathrm{H} 2 \mathrm{O}$ was used as standard. Two-fold dilutions of standard were prepared at the highest concentration of $50 \mathrm{pg} / \mathrm{ml}$. Reagents and samples were kept refrigerated. Substrate solution was prepared just before the assay. MPO activity expresses the amount of enzyme that is able to degrade $1 \mu \mathrm{M}$ of peroxide/min and it is expressed as $\mathrm{U} / \mathrm{g}$ tissue weight.

\section{Preparation of Histological Samples}

Sections of the colon were taken from each animal and preserved in neutral buffered formaline for subsequent histological analysis. Sections were stained using haematoxylin and eosin for further scoring.

\section{Statistical Analysis}

Release of cytokines from PBMC's was compared using twoway ANOVA and Tukey post-test or unpaired student's $t$-test as appropriate. Weight change, colon weight and MPO activity were compared using one-way-ANOVA and Bonferroni posttest, while clinical and pathological scores were analyzed by a Kruskal-Wallis-test for non-parametric data with a Dunn's posttest. All statistical analyses and graphs were done using GraphPad Prism 8 (GraphPad Software, USA).

\section{RESULTS}

\section{hBD2 Modulated the Effects of Toll-Like Receptor Ligands in PBMC's}

We selected human PBMCs challenged with LPS as an ex vivo read out model to assess the anti-inflammatory potential of hBD2. While LPS-challenged PBMCs secreted ample amount of interleukin $1-\beta$ (IL-1 $\beta$ ) (Figure 1A) and TNF- $\alpha$ (Figure 1B), co-treatment with increasing doses of hBD2 consistently mitigated release of both cytokines. hBD2 is a 
positively charged peptide and could potentially bind to the negatively charged LPS, hence mediate the observed effect indirectly without interfering with the pathway. To investigate this possibility, we included an alternative toll like receptor (TLR) ligand, Pam3CSK4; a neutral/negative charged synthetic peptide. As shown in Figure 1, hBD2 significantly reduced the Pam3CSK 4 induced release of IL- $1 \beta$ and TNF- $\alpha$, corroborating a strong anti-inflammatory effect of hBD2 on human PBMCs ex vivo.

We next evaluated if the immune modulating capabilities of hBD2 could be extended to colitis patients. This patient group is known to exhibit an altered response to immunomodulatory stimuli compared to healthy controls. We therefore expanded the proinflammatory panel to also include interferon (INF)- $\boldsymbol{\gamma}$, IL-12p70, and IL-23. Despite the low n-size in this proof-ofconcept sub-experiment, hBD2 treatment successfully attenuated the proinflammatory immune response in LPS-stimulated PBMCs (Figure 2).

\section{Cytokine Production of DC's Was Affected by hBD2 in a TLR- and CCR2-Dependent Manner}

Since PBMCs comprise a variety of cell types we aimed to characterize the responsive cell type, and furthermore the receptor that was targeted by $\mathrm{hBD} 2$. DCs upregulate cytokine production when their TLRs engage their cognate ligands (29). Thus, we hypothesized that DC mediated cytokine secretion was affected by hBD2. We generated human mo-DCs and murine BM-DCs in vitro, and subsequently challenged them with LPS with or without two different concentrations of hBD2. Similar to the previously reported PBMC response (Figures 1, 2), hBD2 treatment dose-dependently curbed TNF- $\alpha$ production in LPSchallenged DCs (Figures 3A,B).

To test whether the hBD2-mediated cytokine modulation was restricted to TLR signaling, we next investigated the cytokine production of BM-DCs stimulated with a TLR-independent cytokine cocktail. While hBD2 treatment alleviated LPS-induced TNF- $\alpha$, IL-12p70, and IL-1 $\beta$ secretion concomitant with a substantial induction of the anti-inflammatory cytokine, IL-10, same treatment failed to modulate TLR-independent activation of BM-DCs (Figures 3C,D and Figures S1B,C).

Since $\mathrm{hBD} 2$ is able to bind to $\mathrm{G}$ protein-coupled receptors expressed on monocytes and DCs (22), we pretreated BMDCs with pertussis toxin prior to the stimulation with LPS and $\mathrm{hBD} 2$. Inhibition of $\mathrm{G}$ protein-coupled receptor signaling prevented the observed immunomodulatory capacity of hBD2. Thus, BM-DCs pre-treated with pertussis toxin and stimulated with LPS and hBD2 showed similar TNF- $\alpha$, IL- $1 \beta$, IL-10, and IL12 p70 secretion compared to BM-DCs treated solely with LPS (Figures 3E,F and Figures S1D,E).

To specify the $G$ protein-coupled receptor interaction of hBD2 we pre-treated BM-DCs with the CCR2 specific inhibitor, RS504393, and subsequently stimulated with LPS and hBD2. Pretreatment with RS504393 prevented the anti-inflammatory effect of hBD2 (Figures 3G,H and Figures S1F,G). Together these data demonstrate a central involvement of CCR2 in hBD2-mediated
DC cytokine modulation; a trait that was shared between human (Figure S1A) and mouse DCs.

\section{hBD2 Modulates NF- $\kappa B$ and CREB Phosphorylation}

NF- $\kappa \mathrm{B}$ represents a key signaling pathway triggered by TLRs. This pathway can also be activated by the proinflammatory cytokines TNF- $\alpha$ and IL-1 $\beta$ (30). NF- $\kappa$ B activity is mediated by direct interaction with the CREB coactivator CBP. However, phosphorylated CREB, that can be induced by $G$ proteincoupled receptors, needs in addition CBP to compete with NF$\kappa \mathrm{B}$ and thereby limiting the NF- $\mathrm{B}$ activity (31). We analyzed the NF- $\kappa \mathrm{B}$ and CREB phosphorylation of hBD2 treated BMDCs. Stimulation with proinflammatory cytokines showed an increase in NF- $\kappa \mathrm{B}$ phosphorylation although to a lower extent than what was observed during LPS stimulation. Co-incubation of both stimuli with hBD2 showed only a reduced NF- $\mathrm{B}$ phosphorylation when BM-DCs were treated with the TLR ligand LPS in combination with hBD2 (Figures 4A,I). However, pre-treatment with the CCR2 inhibitor RS504393 prior to stimulation showed comparable levels of NF- $\kappa$ B phosphorylation irrespective of hBD2 treatment (Figures 4B,I). CCR2 inhibition therefore prevented the $\mathrm{hBD} 2$-mediated reductions in NF- $\kappa \mathrm{B}$ activation. Although the mechanism behind this observation remains elusive, LPS-challenged BM-DCs showed reduced maturation status when stimulated with hBD2, corroborated by lower levels of their key activation markers, MHCII and CD86 (Figures 4C,E). Again, pre-treatment with the CCR2 inhibitor prevented this lower expression (Figures 4D,F). We hypothesized that the CREB signaling pathway could counter NF- $\kappa$ B phosphorylation. We therefore analyzed the CREB phosphorylation status in a next step of experiments. We demonstrated that triggering $G$ protein-coupled receptors led to an increase in CREB phosphorylation (Figures 4G,I) and simultaneously to a reduced NF- $\kappa$ B phosphorylation (Figure 4A), suggesting that phosphorylated CREB competes with NF- $\kappa$ B for their mutual cofactor, CBP. In contrast, pretreatment with the CCR2 inhibitor prevented the increase in CREB phosphorylation (Figures 4H,I).

\section{Recombinant hBD2 Showed Good Tolerability and Rapidly Entered the Bloodstream After Subcutaneous Administration, Hence Allowing Systemic Immunomodulatory Actions}

To identify possible toxicity of recombinant expressed hBD2 we first addressed the hemolytic potential of hBD2 on human red blood cells. As shown in Figure S2A we could not detect any hemolytic effect of $\leq 300 \mu \mathrm{g} / \mathrm{ml} \mathrm{hBD} 2$. We next tested the effect on the viability of murine fibroblasts. No negative effect of hBD2 up to a concentration of $1750 \mu \mathrm{g} / \mathrm{ml}$ could be identified (Figure S2B). Combined, these data corroborates high in vitro tolerability. To assess hBD2 toxicity in vivo, NMRI mice were challenged s.c. with different doses of hBD2 and monitored for 4 days for the development of clinical symptoms. On day 4 , mice were euthanized for necropsy. Table 1 records the clinical 
A

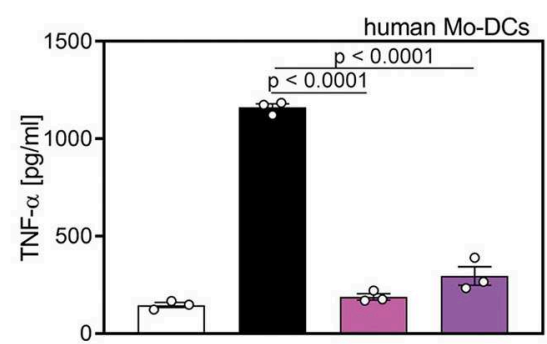

Medium

LPS

hBD2 $100 \mu \mathrm{g} / \mathrm{m}$

hBD2 $10 \mu \mathrm{g} / \mathrm{ml}$

C

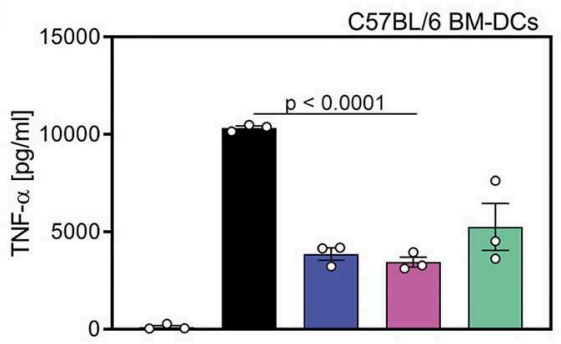

Medium

LPS

hBD2 $100 \mu \mathrm{g} / \mathrm{ml}$.

E

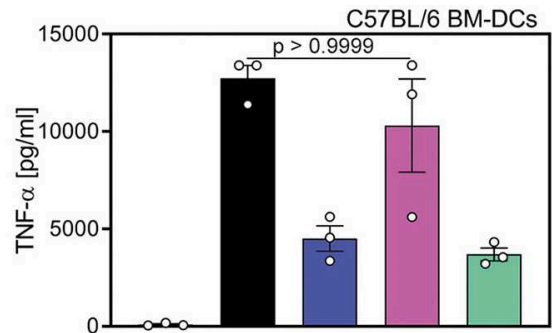

Medium

LPS

TNF-a, IL-6, IL-1ß

hBD2 $100 \mu \mathrm{g} / \mathrm{ml}$

pertussis toxin
B

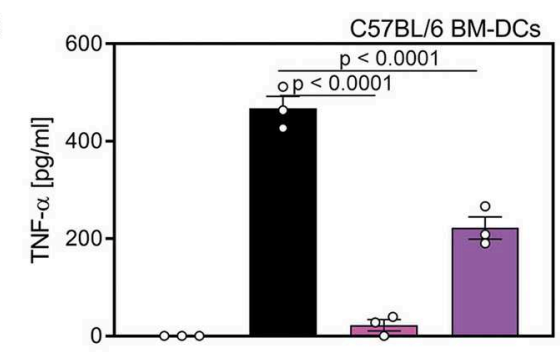

Medium

LPS

hBD2 $100 \mu \mathrm{g} / \mathrm{ml}$

hBD2 $10 \mu \mathrm{g} / \mathrm{ml}$

D

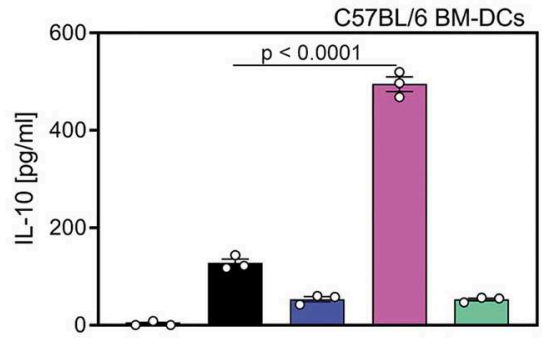

Medium

LPS

TNF- $\alpha, I L-6, I L-1 \beta-$

hBD2 $100 \mu \mathrm{g} / \mathrm{ml}$.

F

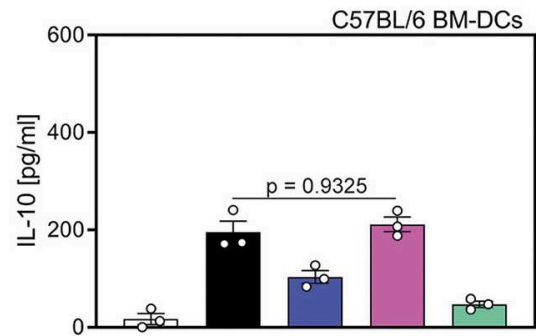

Medium

LPS

TNF- $a$, IL-6, IL-1ß

hBD2 $100 \mu \mathrm{g} / \mathrm{ml}$

pertussis toxin
G

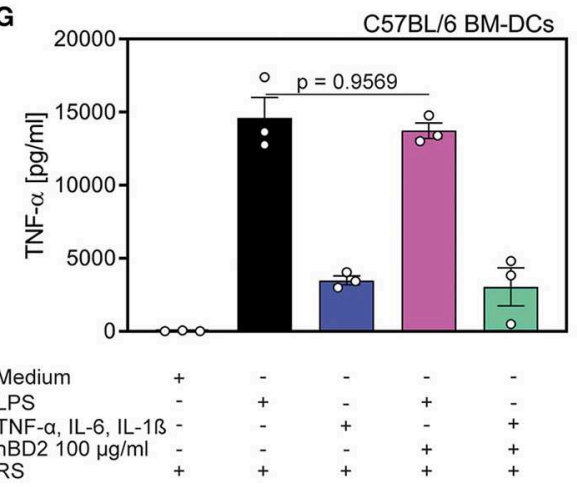

H

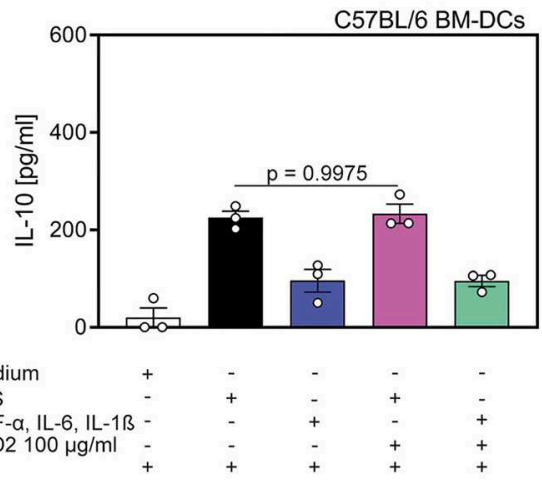

FIGURE 3 | Cytokine production of DC's was affected by hBD2 in a TLR- and CCR2-dependent manner. Human mo-DC's and murine BM-DC's were treated with LPS $(10 \mu \mathrm{g} / \mathrm{ml})$ alone or co-incubated with various concentrations of hBD2 (100 $\mu \mathrm{g} / \mathrm{ml}$ or $10 \mu \mathrm{g} / \mathrm{ml})$. Murine BM-DCs were additionally treated with pertussis toxin or the CCR2 inhibitor RS prior to stimulation with LPS or a cytokine cocktail containing TNF- $\alpha(0.2 \mathrm{mg} / \mathrm{ml}), \mathrm{IL}-6$ (0.2 mg/ml), and IL-1 $\beta$ (0.2 mg/ml). Release of TNF- $\alpha$ in (A) human Mo-DC's and in (B) murine BM-DC's was quantified by ELISA. Release of TNF- $\alpha$ (C,E,G) and IL-10 (D,F,H) in murine BM-DCs was quantified by LEGENDplex. Results are presented as mean $\pm \mathrm{SEM}, n=3$. Statistical test used is one-way ANOVA with Bonferroni post-test. 

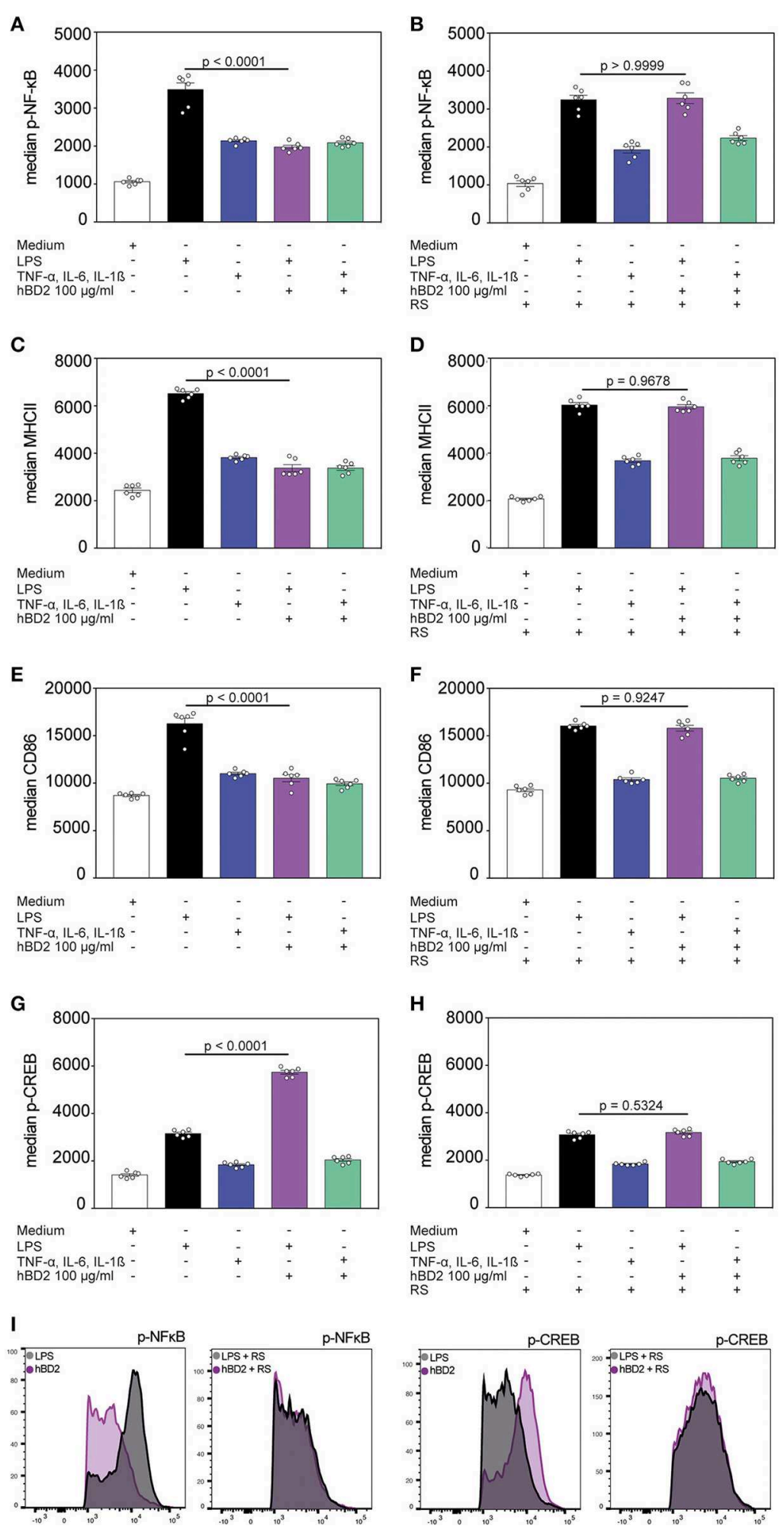

FIGURE 4 | hBD2 modulates NF-кB and CREB phosphorylation. BM-DC's were incubated for 60 min with LPS (10 $\mu \mathrm{g} / \mathrm{ml})$ or a cytokine cocktail containing TNF- $\alpha$ $(0.2 \mathrm{mg} / \mathrm{ml})$, IL-6 $(0.2 \mathrm{mg} / \mathrm{ml})$, and IL-1 $\beta(0.2 \mathrm{mg} / \mathrm{ml})$ alone or in combination with $\mathrm{hBD} 2(100 \mu \mathrm{g} / \mathrm{ml})$. BM-DCs were additionally pretreated with pertussis toxin or the CCR2 inhibitor RS prior to stimulation. The cells were stained with CD11c, MHCll, and CD86 antibodies followed by intracellular staining against $\mathrm{p}-\mathrm{NF}-\mathrm{kB}$ or $\mathrm{p}-\mathrm{CREB}$ and analysis by flow cytometry. Statistical analysis of (A,B) p-NF-kB, (C,D) MHCIl, (E,F) CD86, and (G,H) p-CREB staining. (I) Shows histograms of FACS analysis. Results are presented as mean $\pm \mathrm{SEM}, n=6$. Statistical test used is one-way ANOVA with Bonferroni post-test. 
TABLE 1 | Clinical symptoms after subcutaneous administration of hBD2.

\begin{tabular}{|c|c|c|c|c|c|c|}
\hline \multirow{2}{*}{$\begin{array}{l}\text { Test } \\
\text { compound }\end{array}$} & \multirow{2}{*}{$\begin{array}{l}\text { Dose level } \\
\mathrm{mg} / \mathrm{kg}\end{array}$} & \multicolumn{4}{|c|}{ Clinical signs on the day of dosing } & \multirow{2}{*}{$\begin{array}{c}\text { Necropsy } \\
\begin{array}{c}\text { Macroscopic } \\
\text { findings }\end{array}\end{array}$} \\
\hline & & $\begin{array}{l}\text { No clinical } \\
\text { signs }\end{array}$ & Pruritus & $\begin{array}{l}\text { Clinical } \\
\text { signs }\end{array}$ & $\begin{array}{l}\text { Clinical signs at the end of } \\
\text { the day of dosing }\end{array}$ & \\
\hline Vehicle & 0 & $3 / 3$ & $0 / 3$ & $0 / 3$ & $0 / 3$ & $0 / 3$ \\
\hline \multirow[t]{3}{*}{ HBD2 } & 0.5 & $3 / 3$ & $0 / 3$ & $0 / 3$ & $0 / 3$ & $0 / 3$ \\
\hline & 10 & $0 / 3$ & $3 / 3$ & $3 / 3$ & $0 / 3$ & $0 / 3$ \\
\hline & 40 & $0 / 3$ & $3 / 3$ & 3(severe)/3 & $0 / 3$ & $0 / 3$ \\
\hline
\end{tabular}

symptoms observed. Although minor acute effects were observed (minutes), no adverse effects were observed at necropsy. Shortly after challenge (10-15 min) the mice receiving 10 or $40 \mathrm{mg} / \mathrm{kg}$ hBD2 showed mild clinical signs such as decreased locomotor activity, proneness, ptosis, piloerection, pruritus, bradypnoea, reddish discoloration around the eyes and swelling around the eyes and snout. All clinical signs were transient and only mice dosed with $40 \mathrm{mg} / \mathrm{kg}$ hBD2 were still affected at $60 \mathrm{~min}$ post dosing. Of note, $40 \mathrm{mg} / \mathrm{kg}$ is 40 times higher than the highest dose used in our in vivo experiments. The lowest dose group, 0.5 $\mathrm{mg} / \mathrm{kg} \mathrm{hBD} 2$ and the vehicle group did not develop any clinical signs after systemic challenge. No further clinical signs were observed during the subsequent 4 day observation period nor could we find any abnormalities during necropsy. Additionally, body weight gain and organ weight were recorded. Mice did not show any weight loss nor did the organ weight differ significantly between the groups (Figures S2C,D). In summary, these results indicate that $\mathrm{hBD} 2$ is well-tolerated in vivo.

We next analyzed whether s.c. administered hBD2 would enter the blood stream. For that purpose we injected mice s.c. with 1 or $10 \mathrm{mg} / \mathrm{kg} \mathrm{hBD} 2$ and quantified the amount of hBD2 in serum at different time points after injection. As shown in Figure S2E, hBD2 entered the blood stream rapidly after s.c. injection and remained detectable for more than $2 \mathrm{~h}$. These findings indicate that s.c. applied hBD2 might not only act locally but could also have systemic effects in vivo.

\section{hBD2 Ameliorated the Outcome of DSS Colitis in vivo}

The above described results prompted us to investigate the clinical potential of hBD2 using murine models of experimental colitis with different disease pathologies. First, we assessed the anti-inflammatory and protective effect of hBD2 in DSS colitis. DSS causes a chemical injury to the intestinal mucosa. This results in the exposure of the lamina propria and submucosal compartments to luminal antigens and enteric bacteria which results in inflammation and ulcer formation (32). Treatment of DSS colitis with s.c. administered hBD2 $(0.1 \mathrm{mg} / \mathrm{kg})$ resulted in a significant improvement of colitis; the therapeutic effect was superior to anti-TNF- $\alpha$ treatment (Figure 5). hBD2 prevented excessive weight loss (Figure 5A) and improved the DAI (Figure 4B). Furthermore, scoring of the colonic mucosa for damage revealed a significantly reduced mucosal damage in mice treated with hBD2 (Figure 5C). Histological assessment of colon
(Figure 5D) showed strong mucosal damage caused by DSS, characterized by a massive loss of the crypt architecture. In contrast, treatment with hBD2 prevented this loss of crypts and maintained a normal mucosa, comparable to the naïve mice.

\section{hBD2 Significantly Improved TNBS Colitis in vivo}

We next tested the efficacy of hBD2 in TNBS induced colitis. TNBS reacts with proteins in the colon (haptenation), thus making them immunogenic. TNBS is dissolved in ethanol, which permeabilizes the colonic epithelium. The immunogenic proteins then cause a predominantly Th1 type response restricted to the colon (33). In contrast to DSS colitis, TNBS colitis did not result in weight loss, but rather prevented weight-gain in mice during the time of our experiment. Weight changes were similar between groups, although hBD2 treated mice trended toward increased weight gain from day 1-7 (Figure 6A). Yet, s.c. treatment with $0.1 \mathrm{mg} / \mathrm{kg}$ hBD2 significantly reduced colon weight and a similar tendency was also observed for prednisolone (Figure 6B), indicating a reduced infiltration of inflammatory cells. Finally, s.c. treatment with hBD2 significantly improved the macroscopic (Figure 6C) as well as the microscopic score of mouse colons (Figures 6D,E) comparable with the effect of prednisolone. Microscopic analysis of the colon showed a loss of crypts in diseased mice, while mice receiving $0.1 \mathrm{mg} / \mathrm{kg} \mathrm{hBD} 2$ showed a nearly normal mucosa comparable to prednisolone treated mice.

\section{Protective Effect of hBD2 in T Cell Transfer Colitis}

Finally, we tested hBD2 in a model of $\mathrm{T}$ cell transfer colitis. In this model $\mathrm{CD}^{+} \mathrm{T}$ cells from immunocompetent mice are adoptively transferred into severe combined immunodeficiency (SCID) mice, lacking $\mathrm{T}$ cells. The transferred $\mathrm{T}$ cells respond to enteric bacteria with the release of IL-2 and INF- $\gamma$ (34). The inflammation is restricted to the colon, and extends diffusely from the cecum to the rectum. Besides affecting the lamina propria, the pathogenesis can also be transmural (35). Importantly, in addition to the different disease pathology, this model also results in chronic inflammation as oppose to the acute models (DSS and TNBS) previously examined. Colitis was induced in SCID mice by transferring $\mathrm{CD} 4^{+} / \mathrm{CD} 25^{-} \mathrm{T}$ cells from WT mice. One group of SCID mice did not receive a $\mathrm{T}$ cell transfer (naive). Mice that 
A

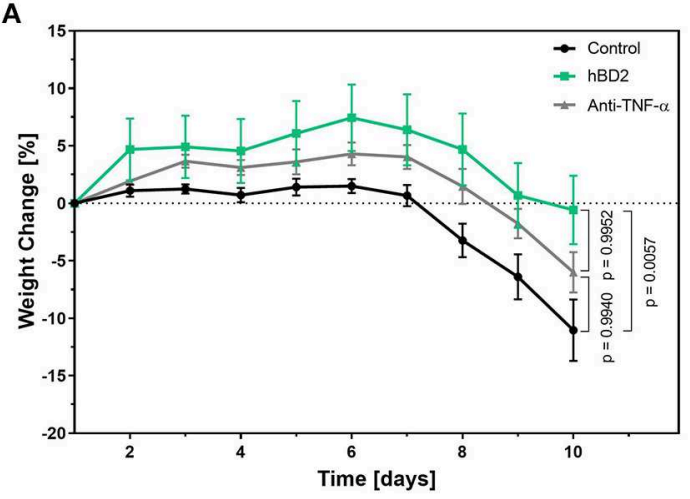

C

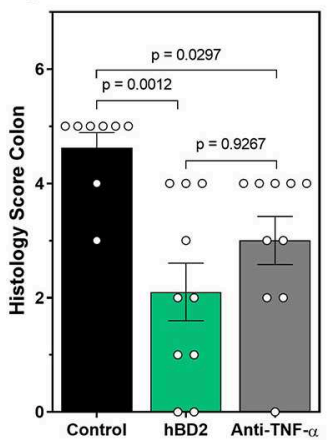

D

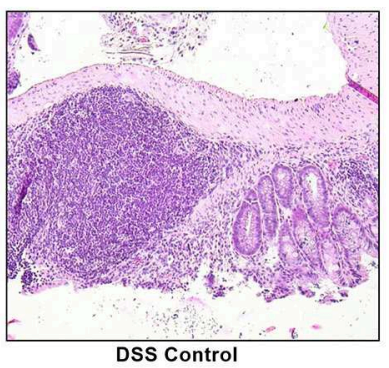

B

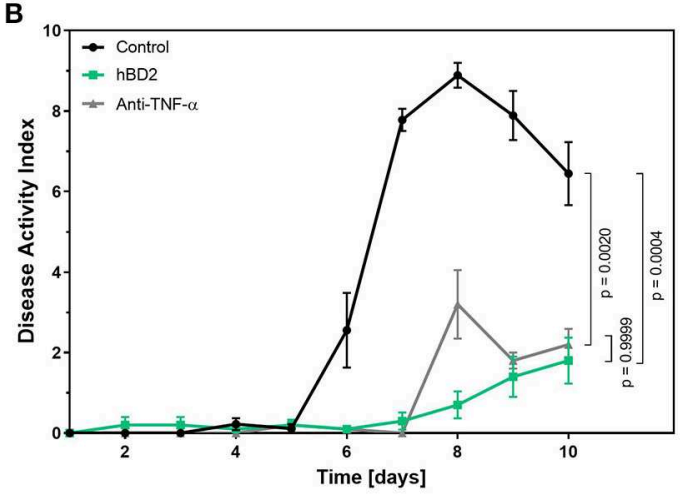

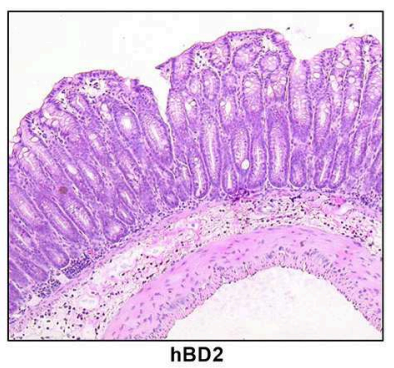

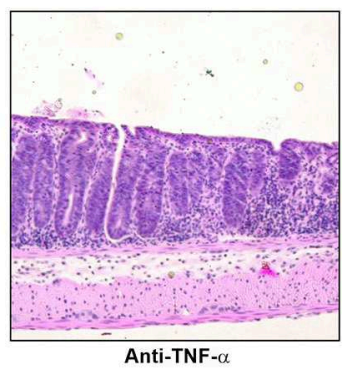

FIGURE 5 | hBD2 ameliorated the outcome of DSS colitis in vivo. Colitis was induced by adding $2 \%$ DSS into the drinking water. On day 8 DSS was removed from the drinking water. Mice were treated either once a day s.c. with $0.1 \mathrm{mg} / \mathrm{kg}$ hBD2 or intraperitoneally with an anti-TNF $\alpha$ antibody (300 $\mu \mathrm{g} / \mathrm{mouse}$ ) on day 1 , 4 , and 8 . (A) Weight change of mice during the experiment, (B) development of DAl, (C) histology score from the colon of the mice at the end of the experiment, and (D) representative images from the colon of differentially treated mice. Results are presented as mean \pm SEM, control group $n=9$ and treated groups $n=10$. Appropriate statistical comparison are shown within the graph by a Kruskal-Wallis-test for non-parametric data with a Dunn's post-test.

received a $\mathrm{T}$ cell transfer gained significantly less weight than naive mice. Based on the chronic nature of this model and the involvement of numerous cell type of the immunological arsenal, we applied two different doses of hBD2 to increase the therapeutic window. Colitis mice treated with $1 \mathrm{mg} / \mathrm{kg} \mathrm{hBD} 2$ s.c. showed less weight loss (Figure 7A) and demonstrated an improved DAI (Figure 7B) in comparison to the $\mathrm{T}$ cell colitis control group. Same trait was observed for the stool score (Figure 7C). The increased scores in the untreated colitis group appeared earlier than in the hBD2 treated group indicating a protective effect of hBD2. Furthermore, treatment with $1 \mathrm{mg} / \mathrm{kg} \mathrm{hBD} 2$ significantly reduced the colon weight (Figure 7D) supporting the conclusion of mitigated inflammation. Only a minor effect of hBD2 on colonic myeloperoxidase activity could be observed (Figure 7E). Histological analysis (Figure 7F) showed pronounced inflammation in colitis mice without treatment, while mice treated with $1 \mathrm{mg} / \mathrm{kg}$ hBD2 showed less signs of inflammation and tissue disruption. Less signs of inflammation were also observed in the colon of dexamethasone treated mice. Furthermore, dexamethasone also improved DAI, stool score and colon weight significantly and was therefore superior to hBD2 in the $\mathrm{T}$ cell transfer model. The high dose of hBD2 (one log higher than previous experiments) seemed essential as
$0.1 \mathrm{mg} / \mathrm{kg} \mathrm{hBD} 2$ did not improve the outcome of T cell mediated colitis (Figures 7A-F).

\section{DISCUSSION}

Herein we report that hBD2 can be used as a systemically administered anti-inflammatory biological. hBD2 is welltolerated, both in vitro, and in vivo. These observations are in line with published in vitro studies testing hBD2 with human mesenchymal stem cells, osteoblasts, keratinocytes, and HeLa cells without observing cytotoxic effects (36). Otte et al. (19) additionally found that hBD2 was well-tolerated by intestinal epithelial cells. Of note and in contrast to hBD2, high concentrations of hBD3 demonstrated cytotoxic effects in human dendritic cells and keratinocytes (37). After subcutaneous injection we observed a dose dependent pruritus of short duration which only occurred at doses magnitudes higher than the later identified therapeutic doses. At all doses (up to $40 \mathrm{mg} / \mathrm{kg}$ ), body weight and organ weights of liver, spleen and kidney were unaffected.

Peak hBD2 drug serum concentrations were also dose dependent and in the range of $2-10 \mu \mathrm{g} / \mathrm{ml}$ after single doses of 1 vs. $10 \mathrm{mg} / \mathrm{kg}$. Using medium concentrations in a similar range we confirmed that hBD2 attenuates inflammatory responses 
A

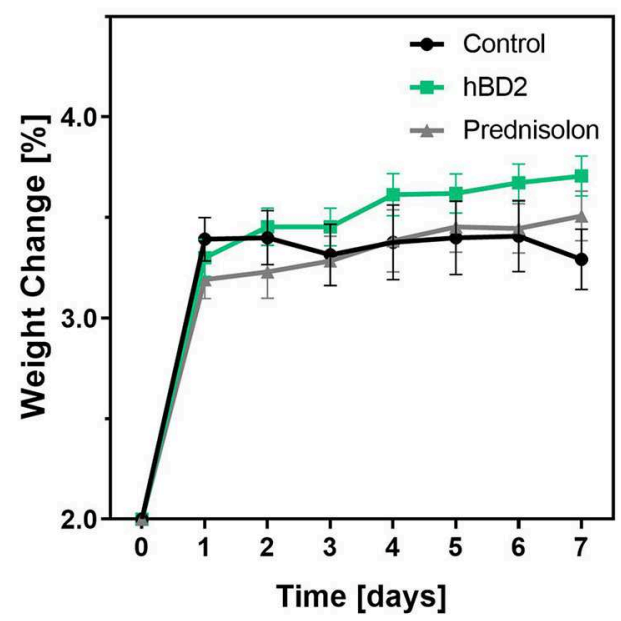

C

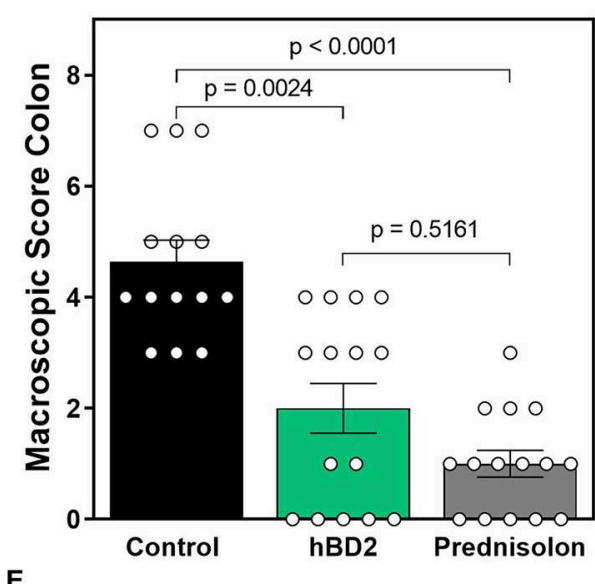

B

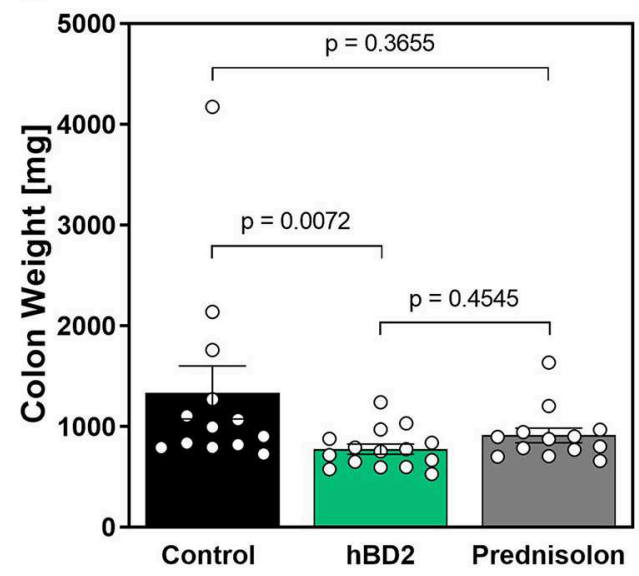

D

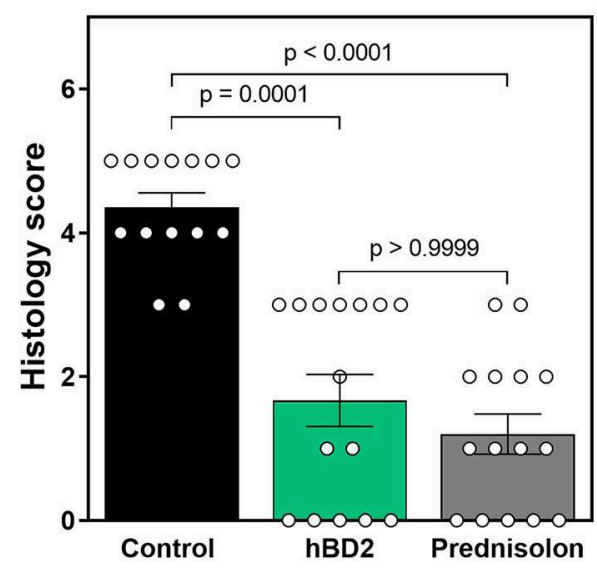

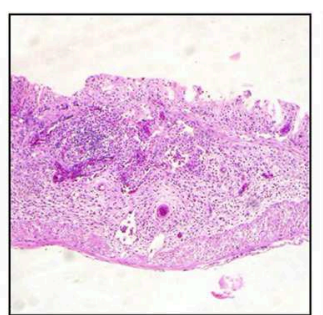

TNBS Control

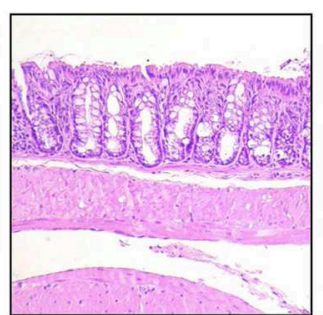

hBD2

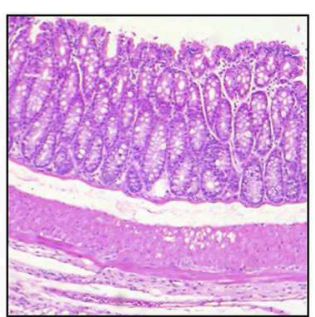

Prednisolon

FIGURE 6 | hBD2 significantly improved TNBS colitis in vivo. Colitis was induced by a single dose of TNBS into the colon. Mice were then treated s.c. with different doses of hBD2 $(0.1 \mathrm{mg} / \mathrm{kg})$ or Prednisolone $(10 \mathrm{mg} / \mathrm{kg})$ once a day and monitored for 7 days. (A) Development of mouse weight during the experiment. After euthanization, the colon of the mice was examined for (B) colon weight, (C) macroscopic abnormalities, and (D) microscopic evidence of inflammation. (E) Representative images from the colon of differentially treated mice are shown. Results are presented as mean \pm SEM, control group $n=14$, prednisolone group $n=14$, and hBD2 group $n=15$. Appropriate statistical comparisons are shown within the graph by a Kruskal-Wallis-test for non-parametric data with a Dunn's post-test.

of human PBMC's in vitro. TNF- $\alpha$, IL-1 $\beta$, and IL-12p70 were consistently reduced after hBD2 treatment, whereas the antiinflammatory cytokine, IL-10, was significantly increased. TNF$\alpha$ is a well-known key inflammatory mediator of IBD and a successful target of modern biologicals in the treatment of IBD and other inflammatory diseases (38). In addition, IL- $1 \beta$ has recently been described to mediate intestinal inflammation in IBD patients with IL-10 receptor deficiency, and is thus proposed as a potential therapeutic target (39). In a follow-up pilot study using 4 colitis patients and 4 healthy controls, we confirmed the 


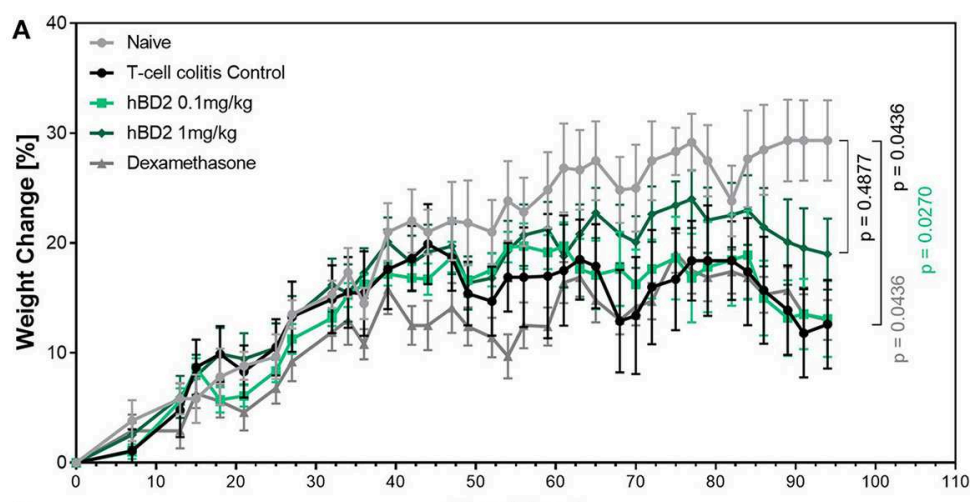

B
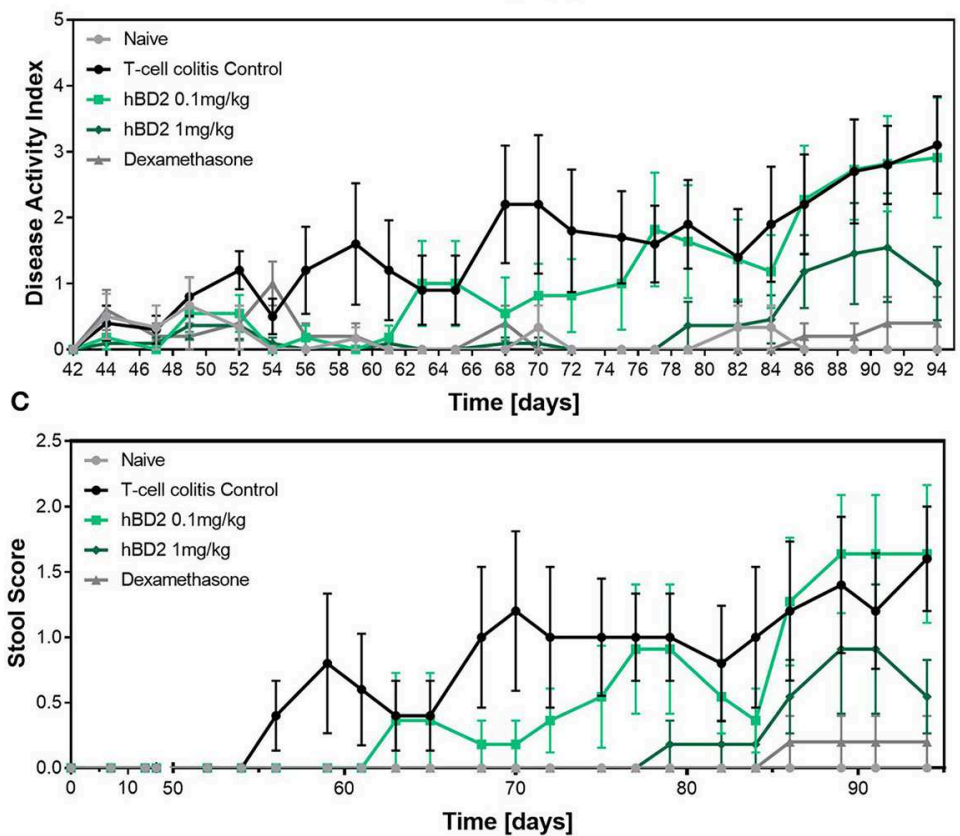

D

F
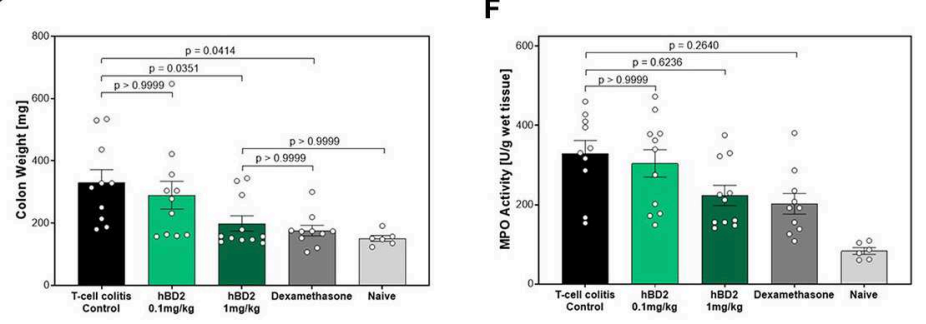

E

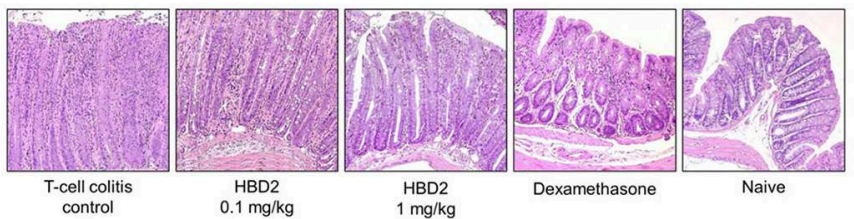

FIGURE 7 | Protective effect of hBD2 in T cell transfer colitis. Colitis was induced by transferring CD4 ${ }^{+} / \mathrm{CD} 25^{-} \mathrm{T}$ cells from WT mice to SCID mice. Development of colitis was observed for 94 days. Daily treatment with hBD2 (0.1 mg/kg or $1 \mathrm{mg} / \mathrm{kg}$, s.c.) and Dexamethasone (0.3 mg/kg, i.p.) started 7 days after the transfer. (A) Weight change of mice during the experiment was monitored as well as (B) development of clinical symptoms as DAl. (C) Alteration of stool consistency was assessed as stool score. At the end of the experiment (D) colon weight was measured and (E) activity of myeloperoxidase (MPO) was quantified. (F) Representative images from the colon of differentially treated mice are shown. Results are presented as mean \pm SEM, $n=6$ (sham treated animals), $n=10$ (vehicle and dexamethasone mice) and $n=11$ (hBD2 mice). Appropriate statistical comparisons are shown within the graph by a Kruskal-Wallis-test for non-parametric data with a Dunn's post-test. 
immunomodulatory capabilities of hBD2 in both groups, lending further credence to the hypothesis that hBD2 might be used as a novel biological to either treat colitis patients or alternatively to keep such patients in remission.

In a next step, we identified DCs as one cell population amongst PBMCs whose cytokine secretion is modulated by $\mathrm{hBD} 2$. Because it is already known that hBD2 is able to induce chemotaxis by binding to the CCR2 receptor (22), we investigated whether the observed hBD2 mediated downregulation of inflammation might depend on CCR2. In line with this hypothesis, the effects of hBD2 in human mo-DC's as well as in murine BM-DC's were completely blocked by a CCR2 inhibitor. We found a potential interaction between the downstream signaling molecules of the TLR and CCR signaling pathways. One possibility is that the signaling molecules NF- $\kappa \mathrm{B}$ and CREB compete for the coactivator CBP. But also other signaling molecules such as the extracellular signal-regulated kinase (ERK) that plays an important role in TLR signaling (40) as well as CCR signaling, by inducing e.g., expression of CCR1 and CCR2 in human monocytic cells may play important roles $(41,42)$. Unfortunately, it is not possible to test the CCR2 dependency of the hBD2 effect in vivo because CCR $2^{-/-}$mice are protected from experimental induced colitis (43).

Based on the feasibility of recombinant hBD2 production (26), negligible toxicity, and strong anti-inflammatory CCR2 dependent modulation of DCs, we hypothesized that hBD2 could be used as a systemic anti-inflammatory biological. This strategy uncouples the classical intra-intestinal functions of hBD2 from their potent immunomodulatory capacity, and thus represents a new paradigm in therapeutic use of antimicrobial peptides. Indeed, subcutaneously administered hBD2 improved the outcome of colitis in three different in vivo models of IBD, namely DSS-, TNBS-, and T-cell transfer-mediated colitis. This is in line with our observation of hBD2 to rapidly enter the blood stream after s.c. administration and is likely mediated by its anti-inflammatory activity on several blood cell populations, and especially the DC fraction, as described above. We therefore tested and found that hBD2 administered s.c. could act as an immune-modulator, attenuating inflammation, that characterizes IBD. This finding is consistent with the observation of Aden et al. (44) who studied the development of colitis in IL23 receptor deficient mice (Il23 $\mathrm{R}^{\triangle \mathrm{IEC}}$ ) and found these to display decreased levels of leukocyte derived IL-22 and of Reg3b, a C-type lectin with antimicrobial activity (45). Systemic administration of Reg3b significantly improved DSS-colitis in Il23R ${ }^{\triangle I E C}$ mice by recruiting IL-22 secreting neutrophils supporting a protective role for Reg3b in colitis (44). In addition, the hBD2-induced wound healing in intestinal epithelial cells in vitro (19) may add another mechanism of action. Finally, rectally applied porcine $\beta$-defensin 2 (pBD2) has been used for the treatment of DSS colitis in mice by Han et al. (46). They found pBD2 to be protective against mucosal injury and disruption of the epithelial barrier associated with DSS colitis. Furthermore, they reported decreased inflammatory infiltrates and expression of inflammatory mediators upon treatment with pBD2 as well as an increase in intestinal tight junction structure and function compared to untreated DSS control mice. In contrast to the local administration employed by Han et al., we provide evidence for a distinct anti-inflammatory effect with systemic application.

Despite ongoing development of therapeutic approaches, new treatment strategies for the management of IBD are still urgently needed. Corticosteroids remain the standard therapeutic options for active CD and UC. However, their beneficial effects are associated with severe side effects such as osteoporosis, moon face, mood disturbances, glaucoma, and hypertension (47). In recent years, several new therapeutics targeting the molecular mechanisms of intestinal and systemic inflammation have been developed. Among these, anti-TNF $\alpha$ antibodies have been the most successful and most commonly used biological (48). However, primary and secondary lack of response as well as serious side effects, limits their use. More recently, antibodies targeting IL-17 in CD and IL-13 in UC have been proposed as IBD management. Yet, despite promising preclinical data, both antibodies failed to improve the outcome of CD or UC (49) in patients. Secukinumab, an anti-IL-17 antibody, even worsened the disease in a clinical trial in CD patients (50) and two antiIL-13 antibodies also failed to produce positive results in clinical trials for UC $(51,52)$. This negative effect of IL-17 blockade may in part be explained by blocking the $\mathrm{hBD} 2$ pathway, which is also mediated by IL- 17 .

In conclusion, the results presented here constitute the first in vivo proof of therapeutic efficacy of a systemically administered human defensin. It is, however, important to stress, that in all tested models, hBD2 were administered before the onset of clinical inflammation. We therefore provide strong evidence for the potential of hBD2 treatment to keep patients in remission, but studies are warranted to examine if hBD2 also exhibits treatment efficacy of acute and relapsed inflammation. The use of natural host defense peptides could provide a new chapter of effective, minimal-side-effect treatment strategies of IBD.

\section{DATA AVAILABILITY STATEMENT}

The datasets generated for this study are available on request to the corresponding author.

\section{ETHICS STATEMENT}

The studies involving human participants were reviewed and approved by the Ethical Committee of the University Hospital Tübingen. The patients/participants provided their written informed consent to participate in this study. The animal study was reviewed and approved by the Novozymes science ethics committee.

\section{AUTHOR CONTRIBUTIONS}

LK, NA, KB, SK, BA, PN, BJ, and JW conceived the study, designed the experiments, and analyzed the data. LK, NA, KB, $\mathrm{BA}$, and CL performed the experiments. SA, DS, and NM contributed reagents, materials, analysis tools, and participated in scientific discussion. LK, NA, ES, PN, BJ, and JW wrote the paper. 


\section{FUNDING}

This study was supported by Novozymes and Deutsche Forschungsgemeinschaft (DFG) Heisenberg Professorship to JW and by DFG (WE 4336/2-3 and WE 43367/7-1). BJ was supported by Novo Nordisk Foundation, grant number: NNF17OC0026698. DS was supported by a Max Eder Research Fellowship of the German Cancer Aid (Deutsche Krebshilfe). The funders had no role in study design, data collection and analysis, decision to publish, or preparation of the manuscript.

\section{REFERENCES}

1. Podolsky DK. Inflammatory bowel disease. N Engl J Med. (2002) 347:417-29. doi: 10.1056/NEJMra020831

2. Ananthakrishnan AN, Khalili H, Song M, Higuchi LM, Richter JM, Nimptsch $\mathrm{K}$, et al. High school diet and risk of Crohn's disease and ulcerative colitis. Inflamm Bowel Dis. (2015) 21:2311-19. doi: 10.1097/MIB.0000000000000501

3. Xavier RJ, Podolsky DK. Unravelling the pathogenesis of inflammatory bowel disease. Nature. (2007) 448:427-34. doi: 10.1038/nature06005

4. Ostaff MJ, Stange EF, Wehkamp J. Antimicrobial peptides and gut microbiota in homeostasis and pathology. EMBO Mol Med. (2013) 5:1465-83. doi: $10.1002 / \mathrm{emmm} .201201773$

5. Cleynen I, Boucher G, Jostins L, Schumm LP, Zeissig S, Ahmad T, et al. Inherited determinants of Crohn's disease and ulcerative colitis phenotypes: a genetic association study. Lancet. (2016) 387:156-67. doi: 10.1016/S0140-6736(15)00465-1

6. Wehkamp J, Harder J, Weichenthal M, Schwab M, Schäffeler E, Schlee $\mathrm{M}$, et al. NOD2 (CARD15) mutations in Crohn's disease are associated with diminished mucosal alpha-defensin expression. Gut. (2004) 53:1658-64. doi: 10.1136/gut.2003.032805

7. Fellermann K, Stange DE, Schaeffeler E, Schmalzl H, Wehkamp J, Bevins CL, et al. A chromosome 8 gene-cluster polymorphism with low human betadefensin 2 gene copy number predisposes to Crohn disease of the colon. Am J Hum Genet. (2006) 79:439-48. doi: 10.1086/505915

8. Wehkamp J, Koslowski M, Wang G, Stange EF. Barrier dysfunction due to distinct defensin deficiencies in small intestinal and colonic Crohn's disease. Mucosal Immunol. (2008) 1:S67-74. doi: 10.1038/mi.2008.48

9. Beisner J, Teltschik Z, Ostaff MJ, Tiemessen MM, Staal FJT, Wang G, et al. TCF-1-mediated Wnt signaling regulates Paneth cell innate immune defense effectors HD-5 and-6: implications for Crohn's disease. Am J Physiol Gastrointest Liver Physiol. (2014) 307:G487-98. doi: 10.1152/ajpgi.0034 7.2013

10. Courth LF, Ostaff MJ, Mailänder-Sánchez D, Malek NP, Stange EF, Wehkamp J. Crohn's disease-derived monocytes fail to induce Paneth cell defensins. Proc Natl Acad Sci USA. (2015) 112:14000-5. doi: 10.1073/pnas.1510084112

11. Sidiq T, Yoshihama S, Downs I, Kobayashi KS. Nod2: a critical regulator of ileal microbiota and Crohn's disease. Front Immunol. (2016) 7:367. doi: 10.3389/fimmu.2016.00367

12. Cadwell K, Liu JY, Brown SL, Miyoshi H, Loh J, Lennerz JK, et al. A key role for autophagy and the autophagy gene Atg1611 in mouse and human intestinal Paneth cells. Nature. (2008) 456:259-63. doi: 10.1038/nature07416

13. Stappenbeck TS. Paneth cell development, differentiation, and function: new molecular cues. Gastroenterology. (2009) 137:30-3. doi: 10.1053/j.gastro.2009.05.013

14. Wehkamp J, Stange EF. Paneth's disease. J Crohn's Colitis. (2010) 4:523-31. doi: 10.1016/j.crohns.2010.05.010

15. Lala S, Ogura Y, Osborne C, Hor SY, Bromfield A, Davies S, et al. Crohn's disease and the NOD2 gene: a role for paneth cells. Gastroenterology. (2003) 125:47-57. doi: 10.1016/S0016-5085(03)00661-9

16. van Es JH, Jay P, Gregorieff A, van Gijn ME, Jonkheer S, Hatzis P, et al. Wnt signalling induces maturation of Paneth cells in intestinal crypts. Nat Cell Biol. (2005) 7:381-6. doi: 10.1038/ncb1240

\section{ACKNOWLEDGMENTS}

We thank Marion Strauß and Jutta Bader for excellent technical assistance and Daniela Mailänder-Sánchez for the helpful discussions.

\section{SUPPLEMENTARY MATERIAL}

The Supplementary Material for this article can be found online at: https://www.frontiersin.org/articles/10.3389/fimmu. 2020.00093/full\#supplementary-material

17. Dale BA, Kimball JR, Krisanaprakornkit S, Roberts F, Robinovitch M, O’Neal $\mathrm{R}$, et al. Localized antimicrobial peptide expression in human gingiva. $J$ Periodont Res. (2001) 36:285-94. doi: 10.1034/j.1600-0765.2001.360503.x

18. Schröder JM, Harder J. Human beta-defensin-2. Int J Biochem Cell Biol. (1999) 31:645-51. doi: 10.1016/S1357-2725(99)00013-8

19. Otte JM, Werner I, Brand S, Chromik AM, Schmitz F, Kleine M, et al. Human beta defensin 2 promotes intestinal wound healing in vitro. J Cell Biochem. (2008) 104:2286-97. doi: 10.1002/jcb.21787

20. Baroni A, Donnarumma G, Paoletti I, Longanesi-Cattani I, Bifulco K, Tufano MA, et al. Antimicrobial human beta-defensin-2 stimulates migration, proliferation and tube formation of human umbilical vein endothelial cells. Peptides. (2009) 30:267-72. doi: 10.1016/j.peptides.2008.11.001

21. Yang D, Chertov O, Bykovskaia SN, Chen Q, Buffo MJ, Shogan J, et al. Betadefensins: linking innate and adaptive immunity through dendritic and T cell CCR6. Science. (1999) 286:525-8. doi: 10.1126/science.286.5439.525

22. Röhrl J, Yang D, Oppenheim JJ, Hehlgans T. Human beta-defensin 2 and 3 and their mouse orthologs induce chemotaxis through interaction with CCR2. J Immunol. (2010) 184:6688-94. doi: 10.4049/jimmunol.0903984

23. Nuding S, Fellermann K, Wehkamp J, Stange EF. Reduced mucosal antimicrobial activity in Crohn's disease of the colon. Gut. (2007) 56:1240-7. doi: 10.1136/gut.2006.118646

24. Hanauer SB, Feagan BG, Lichtenstein GR, Mayer LF, Schreiber S, Colombel JF, et al. Maintenance infliximab for Crohn's disease: the ACCENT I randomised trial. Lancet. (2002) 359:1541-9. doi: 10.1016/S0140-6736(02)08512-4

25. Hanauer SB, Sandborn WJ, Rutgeerts P, Fedorak RN, Lukas M, MacIntosh D, et al. Human anti-tumor necrosis factor monoclonal antibody (adalimumab) in Crohn's disease: the CLASSIC-I trial. Gastroenterology. (2006) 130:323-33; quiz 591. doi: 10.1053/j.gastro.2005.11.030

26. Møller TSB, Hay J, Saxton MJ, Bunting K, Petersen EI, Kjærulff S, et al. Human $\beta$-defensin-2 production from S. cerevisiae using the repressible MET17 promoter. Microb Cell Fact. (2017) 16:11. doi: 10.1186/s12934-017-0627-7

27. Borenfreund E, Puerner JA. Toxicity determined in vitro by morphological alterations and neutral red absorption. Toxicol Lett. (1985) 24:119-24. doi: 10.1016/0378-4274(85)90046-3

28. Lutz MB, Kukutsch N, Ogilvie AL, Rössner S, Koch F, Romani N, et al. An advanced culture method for generating large quantities of highly pure dendritic cells from mouse bone marrow. J Immunol Methods. (1999) 223:7792. doi: 10.1016/S0022-1759(98)00204-X

29. Re F, Strominger JL. Heterogeneity of TLR-induced responses in dendritic cells: from innate to adaptive immunity. Immunobiology. (2004) 209:191-8. doi: 10.1016/j.imbio.2004.03.005

30. Ghosh S, Hayden MS. New regulators of NF-kappaB in inflammation. Nat Rev Immunol. (2008) 8:837-48. doi: 10.1038/nri2423

31. Parry GC, Mackman N. Role of cyclic AMP response element-binding protein in cyclic AMP inhibition of NF-kappaB-mediated transcription. J Immunol. (1997) 159:5450-6.

32. Low D, Nguyen DD, Mizoguchi E. Animal models of ulcerative colitis and their application in drug research. Drug Des Devel Ther. (2013) 7:1341-57. doi: 10.2147/DDDT.S40107

33. Foligné B, Nutten S, Steidler L, Dennin V, Goudercourt D, Mercenier A, Pot B. Recommendations for improved use of the murine TNBS-induced colitis model in evaluating anti-inflammatory properties of lactic acid bacteria: 
technical and microbiological aspects. Dig Dis Sci. (2006) 51:390-400. doi: 10.1007/s10620-006-3143-x

34. Brimnes J, Reimann J, Nissen M, Claesson M. Enteric bacterial antigens activate $\mathrm{CD} 4(+) \mathrm{T}$ cells from scid mice with inflammatory bowel disease. Eur J Immunol. (2001) 31:23-31. doi: 10.1002/1521-4141(200101)31:1<23::AIDIMMU23>3.0.CO;2-2

35. Leach MW, Bean AG, Mauze S, Coffman RL, Powrie F. Inflammatory bowel disease in C.B-17 scid mice reconstituted with the CD45RBhigh subset of CD4+ T cells. Am J Pathol. (1996) 148:1503-15.

36. Warnke PH, Voss E, Russo PAJ, Stephens S, Kleine M, Terheyden H, et al. Antimicrobial peptide coating of dental implants: biocompatibility assessment of recombinant human beta defensin-2 for human cells. Int J Oral Maxillofac Implants. (2013) 28:982-8. doi: 10.11607/jomi.2594

37. Leelakanok N, Fischer CL, Bates AM, Guthmiller JM, Johnson GK, Salem AK, et al. Cytotoxicity of HBD3 for dendritic cells, normal human epidermal keratinocytes, hTERT keratinocytes, and primary oral gingival epithelial keratinocytes in cell culture conditions. Toxicol Lett. (2015) 239:90-6. doi: 10.1016/j.toxlet.2015.09.006

38. Plevy SE, Landers CJ, Prehn J, Carramanzana NM, Deem RL, Shealy D, et al. A role for TNF-alpha and mucosal T helper-1 cytokines in the pathogenesis of Crohn's disease. J Immunol. (1997) 159:6276-82.

39. Shouval DS, Biswas A, Kang YH, Griffith AE, Konnikova L, Mascanfroni ID, et al. Interleukin $1 \beta$ mediates intestinal inflammation in mice and patients with interleukin 10 receptor deficiency. Gastroenterology. (2016) 151:1100-4. doi: 10.1053/j.gastro.2016.08.055

40. Dumitru CD, Ceci JD, Tsatsanis C, Kontoyiannis D, Stamatakis K, Lin $\mathrm{JH}$, et al. TNF-alpha induction by LPS is regulated posttranscriptionally via a Tpl2/ERK-dependent pathway. Cell. (2000) 103:1071-83. doi: 10.1016/S0092-8674(00)00210-5

41. Tang CH, Tsai CC. CCL2 increases MMP-9 expression and cell motility in human chondrosarcoma cells via the Ras/Raf/MEK/ERK/NFкB signaling pathway. Biochem Pharmacol. (2012) 83:335-44. doi: 10.1016/j.bcp.2011.11.013

42. Ko J, Yun CY, Lee JS, Kim JH, Kim IS. p38 MAPK and ERK activation by 9-cis-retinoic acid induces chemokine receptors CCR1 and CCR2 expression in human monocytic THP-1 cells. Exp Mol Med. (2007) 39:129-38. doi: $10.1038 / \mathrm{emm} .2007 .15$

43. Andres PG, Beck PL, Mizoguchi E, Mizoguchi A, Bhan AK, Dawson T, et al. Mice with a selective deletion of the CC chemokine receptors 5 or 2 are protected from dextran sodium sulfate-mediated colitis: lack of CC chemokine receptor 5 expression results in a NK1.1+ lymphocyte-associated Th2-type immune response in the intestine. J Immunol. (2000) 164:6303-12. doi: 10.4049/jimmunol.164.12.6303

44. Aden K, Rehman A, Falk-Paulsen M, Secher T, Kuiper J, Tran F, et al. Epithelial IL-23R signaling licenses protective IL-22 responses in intestinal inflammation. Cell Rep. (2016) 16:2208-18. doi: 10.1016/j.celrep.2016.07.054
45. Cash HL. Symbiotic bacteria direct expression of an intestinal bactericidal lectin. Science. (2006) 313:1126-30. doi: 10.1126/science.1127119

46. Han F, Zhang H, Xia X, Xiong H, Song D, Zong X, et al. Porcine $\beta$ defensin 2 attenuates inflammation and mucosal lesions in dextran sodium sulfate-induced colitis. J Immunol. (2015) 194:1882-93. doi: 10.4049/jimmunol.1402300

47. Irving PM, Gearry RB, Sparrow MP, Gibson PR. Review article: appropriate use of corticosteroids in Crohn's disease. Aliment Pharmacol Ther. (2007) 26:313-29. doi: 10.1111/j.1365-2036.2007.03379.x

48. Chan $\mathrm{HCH}, \mathrm{Ng}$ SC. Emerging biologics in inflammatory bowel disease. $J$ Gastroenterol. (2017) 52:141-50. doi: 10.1007/s00535-016-1283-0

49. Bilsborough J, Targan SR, Snapper SB. Therapeutic targets in inflammatory bowel disease: current and future. Am J Gastroenterol Suppl. (2016) 3:ajgsup201618. doi: 10.1038/ajgsup.2016.18

50. Hueber W, Sands BE, Lewitzky S, Vandemeulebroecke M, Reinisch W, Higgins PDR, et al. Secukinumab, a human anti-IL-17A monoclonal antibody, for moderate to severe Crohn's disease: unexpected results of a randomised, double-blind placebo-controlled trial. Gut. (2012) 61:1693-700. doi: 10.1136/gutjnl-2011-301668

51. Danese S, Rudzinski J, Brandt W, Dupas JL, Peyrin-Biroulet L, Bouhnik $\mathrm{Y}$, et al. Tralokinumab for moderate-to-severe UC: a randomised, double-blind, placebo-controlled, phase IIa study. Gut. (2015) 64:243-9. doi: 10.1136/gutjnl-2014-308004

52. Reinisch W, Panés J, Khurana S, Toth G, Hua F, Comer GM, et al. Anrukinzumab, an anti-interleukin 13 monoclonal antibody, in active UC: efficacy and safety from a phase IIa randomised multicentre study. Gut. (2015) 64:894-900. doi: 10.1136/gutjnl-2014-308337

Conflict of Interest: KB, SK, and BA was employed by Novozymes. PN was employed by Defensin Therapeutics. PN and JW hold shares of Defensin Therapeutics. Defensin Therapeutics holds patents on treatment with defensins.

The remaining authors declare that the research was conducted in the absence of any commercial or financial relationships that could be construed as a potential conflict of interest.

Copyright (C) 2020 Koeninger, Armbruster, Brinch, Kjaerulf, Andersen, Langnau, Autenrieth, Schneidawind, Stange, Malek, Nordkild, Jensen and Wehkamp. This is an open-access article distributed under the terms of the Creative Commons Attribution License (CC BY). The use, distribution or reproduction in other forums is permitted, provided the original author $(s)$ and the copyright owner(s) are credited and that the original publication in this journal is cited, in accordance with accepted academic practice. No use, distribution or reproduction is permitted which does not comply with these terms. 